UNIVERSIDADE DE SÃO PAULO

INSTITUTO DE PSICOLOGIA

NATALIA MINGIONE DA FONSECA

EFEITOS DE WORKSHOP DE PSICOTERAPIA ANALÍTICA

FUNCIONAL SOBRE HABILIDADES TERAPÊUTICAS

São Paulo 
NATALIA M. DA FONSECA

\section{EFEITOS DE WORKSHOP DE PSICOTERAPIA ANALÍTICA FUNCIONAL SOBRE HABILIDADES TERAPÊUTICAS}

(Versão corrigida)

Dissertação de Mestrado apresentada ao Programa de PósGraduação em Psicologia Clínica do Instituto de Psicologia da Universidade de São Paulo para a obtenção do título de Mestre em Psicologia.

Área de concentração:

Psicologia Clínica.

Orientadora: Profa. Dra. Sonia B. Meyer 


\begin{abstract}
AUTORIZO A REPRODUÇÃO E DIVULGAÇÃO TOTAL OU PARCIAL DESTE TRABALHO, POR QUALQUER MEIO CONVENCIONAL OU ELETRÔNICO, PARA FINS DE ESTUDO E PESQUISA, DESDE QUE CITADA A FONTE.
\end{abstract}

Catalogação na publicação Biblioteca Dante Moreira Leite

Instituto de Psicologia da Universidade de São Paulo

Fonseca, Natalia Mingione da.

Efeitos de workshop de psicoterapia analítica funcional sobre habilidades terapêuticas / Natalia Mingione da Fonseca; orientadora Sonia Beatriz Meyer -- São Paulo, 2016.

$95 \mathrm{f}$.

Dissertação (Mestrado - Programa de Pós-Graduação em Psicologia. Área de Concentração: Psicologia Clínica) - Instituto de Psicologia da Universidade de São Paulo.

1. Terapia comportamental 2. Delineamento experimental 3. Categorização 4. Processos psicoterapêuticos I. Título.

RC489.B4 
Nome: Fonseca, Natalia Mingione da.

Título: Efeitos de workshop de Psicoterapia Analítica Funcional sobre habilidades terapêuticas

Dissertação apresentada ao Instituto de Psicologia da Universidade de São Paulo como parte dos requisitos para a obtenção do título de Mestre em Psicologia.

Área de concentração: Psicologia Clínica

Orientadora: Profa. Dra. Sonia Beatriz Meyer

Aprovada em:

Banca Examinadora:

Prof. Dr.

Instituição:

Assinatura:

Prof. Dr.

Instituição:

Assinatura:

Prof. Dr.

Instituição:

Assinatura: 


\section{AGRADECIMENTOS}

À minha orientadora Sonia Beatriz Meyer, por ter me recebido e por ser sempre tão solícita, gentil e cuidadosa. Sua paixão pela pesquisa clínica é contagiante. Obrigada por estar sempre disposta a conversar, sobre a pesquisa ou qualquer outro assunto, por me ouvir quando precisei e por muitos momentos agradáveis. Agradeço também por compartilhar comigo a mania e as muitas histórias de gatos.

À Alessandra Villas-Bôas, pela indispensável ajuda desde antes mesmo deste projeto surgir, e pelo apoio durante todo esse processo. Sou muito grata por você ter acreditado em mim, me incentivado e me ajudado sempre que eu precisei. Obrigada pelos workshops, por compartilhar tanto conhecimento e por tanto mais que não caberia aqui. Você foi fundamental para tudo isso acontecer.

Ao grupo das reuniões nas tardes de quinta-feira: Alessandra Villas-Bôas, Claudia Oshiro, Rodrigo Xavier, Jan Leonardi. Além dos valiosos apontamentos e contribuições metodológicas, vocês proporcionaram ótimos momentos de descontração e os muitos e imprescindíveis cafés com gordices. Sentirei saudades das reuniões.

Aos alunos da Claudia que, embora nos víssemos com menor frequência, também fizeram contribuições importantes e compartilharam momentos produtivos, além de muitas e muitas risadas: Joana Vartanian, Alan Souza Aranha, Gabriela Lima, Daniel Assaz.

Aos terapeutas e clientes participantes desta pesquisa, que tiveram a coragem e a gentileza de gravar suas sessões, tornando possível a realização dessa pesquisa. 
Aos meus clientes, por nutrirem minha paixão por essa profissão, diante de melhoras a olhos vistos. Agradeço, inclusive, pelas frustrações, que me motivam a continuar estudando e a melhorar minha prática profissional continuamente.

À Joana Vartanian e Hamilton Mendes, por se disponibilizarem prontamente a ajudar, de forma tão gentil e responsável.

Às familiares e amigas: Fê, Tata, Karu, Ana Luiza, Paulinha, Taes, por me apoiarem e incentivarem, mesmo que isso implicasse em algumas ausências minhas. Agradeço também por trazerem leveza e alegria, o que com certeza me ajudou a ter mais fôlego durante esse processo.

Ao meu amor, Robson Rocha, por estar sempre ao meu lado, me apoiando e sendo a melhor companhia que eu poderia ter. Obrigada pela paciência, pelos cuidados, por transformar a palavra "rotina" em algo lindo e repleto de amor e carinho. Sua presença na minha vida faz com que todas as dificuldades e momentos de crise pareçam pequenos. Além de tudo, agradeço pela minuciosa revisão. 


\section{RESUMO}

A Psicoterapia Analítica Funcional (FAP) tem como proposta a análise e intervenção de comportamentos que ocorrem durante a sessão, através de modelagem direta dos comportamentos do cliente. Para realizar a FAP de forma sistemática, alguns repertórios são requeridos do terapeuta, que o conhecimento teórico em si pode não ser capaz de produzir. Por isso, tem-se estudado formas de treino ao terapeuta FAP e sua eficácia. Além de leituras, a maneira mais comum de treino é por meio de supervisões, mas uma forma adicional tem sido utilizada mais recentemente, a de workshops experienciais, com objetivo maior de desenvolver as habilidades desejáveis ao terapeuta FAP. O objetivo do presente estudo foi investigar se esta forma de treino é capaz de produzir aquisições no repertório do terapeuta e se estas mudanças são mantidas três meses após a intervenção. Para isso, dois terapeutas participaram de delineamento experimental de linha de base múltipla, e passaram por um workshop (variável independente - VI). Foram utilizados para análise dos dados os instrumentos Functional Analytic Psychotherapy Rating Scale (FAPRS) e a Escala de Impacto da FAP (FAPIS). A análise dos dados mostrou que, após o workshop, ambos os terapeutas passaram a prover consequências (TRB2) aos comportamentos de melhora do cliente (CCR2) com maior eficiência, e um dos terapeutas passou a evocar mais comportamentos "problema" (CCR1) após o treino. A Cliente 1 emitiu mais CCR1 na fase experimental, enquanto o Cliente 2 passou a emitir mais CCR2 após a introdução da VI. Os dados da FAPIS mostraram que ambos os terapeutas relataram ter adquirido habilidades relacionadas à aplicação principalmente das Regras 2 e 3 da FAP.

Palavras-chave: Terapia Comportamental, Delineamento Experimental, Categorização, Processos psicoterapêuticos 


\begin{abstract}
Functional Analytic Psychotherapy proposes to analyze and do interventions in behaviors that occur during sessions, through direct shaping of client's behaviors. To do FAP in a systematic way, some repertoires are required of the therapist that theoretical knowled ge may not be able to provide. Therefore, studies have been carried out on training methods for FAP therapists and its efficacy. Besides readings, the most common form of training is through supervisions, but a new additional way is through experiential workshops, whose goal is to develop desirable skills in FAP therapists. The aim of this study was to investigate if this form of training is capable of producing repertoire acquisitions to therapists and if these changes maintain three months after the intervention. For this, two therapists participated in a multiple-baseline experimental design, and did a workshop (independent variable - IV). To analyze the data, two instruments were used: the Functional Analytic Psychotherapy Rating Scale (FAPRS) and the FAP Impact Scale (FAPIS). Results show that, after the workshop, both therapists provided consequences (TRB2) to client's improvement behaviors (CRB2) more effectively, and one of the therapists evoked more problem behaviors (CRB1). Client 1 emitted more CRB1 in experimental phase, whereas C2 emitted more CRB2. FAPIS data showed that therapists reported that they have acquired more FAP-related skills, especially the ones related to Rules 2 and 3.
\end{abstract}

Keywords: Behavioral Therapy, Experimental Design, Categorization, Psychotherapeutic processes. 


\section{LISTA DE FIGURAS}

Figura 1. Delineamento experimental de linha de base múltipla, com as sessões em que haveria coleta de dados

Figura 2. Delineamento de linha de base múltipla com duas linhas de base, em que os pontos de coleta de dados estão identificados por X e o seguimento por $\mathrm{X}^{*}$. 28

Figura 3. Delineamento de linha de base múltipla conforme ordem cronológica, em que os pontos de coleta de dados estão identificados por X e o seguimento por $\mathrm{X}^{*}$. 28

Figura 4. Média dos CCRs1 em cada etapa para cada cliente 41

Figura 5. Média porcentual dos CCRs2 em cada etapa para cada cliente 42

Figura 6. Média porcentual de Regra 2 em cada etapa para cada terapeuta

Figura 7. Média de TRB1 em cada etapa para cada terapeuta. 44

Figura 8. Média em porcentagem de TRB2 em cada etapa para cada terapeuta 45

Figura 9. Porcentagem de Regras 2 e CCRs2 por sessão .46

Figura 10. Porcentagem de CCRs2 e TRBs2 por sessão 47

Figura 11. Porcentagens de CCRs1 e CCRs2 em todas as sessões da coleta .48

Figura 12. Porcentagens de CCRs1 e TRBS 1 em todas as sessões ...... .50

Figura 13. Porcentagens de ocorrência dos Os 1 e 2 durante a coleta. 


\section{LISTA DE TABELAS}

Tabela 1. Códigos de comportamentos do cliente e descrição .23

Tabela 2. Códigos de comportamentos do terapeuta e descrição 24

Tabela 3. Unidades verbais em cada Etapa para cada díade participante 39

Tabela 4. Porcentagens arredondadas de ocorrência de categorias do FAPRS de terapeuta e cliente por sessão $\quad 40$

Tabela 5. Pontuação atribuídas pelos participantes às questões da FAPIS 53

Tabela 6. Somas e médias das pontuações atribuídas pelos Terapeutas pré e pós-workshop ..54

Tabela 7. Questões cujas diferenças de pontuação pré e pós-workshop foram $\geq 2$ …..............54

Tabela 8. Questões cujas diferenças de pontuação pré e pós-workshop foram $\leq-1$ 55 


\section{LISTA DE ANEXOS}

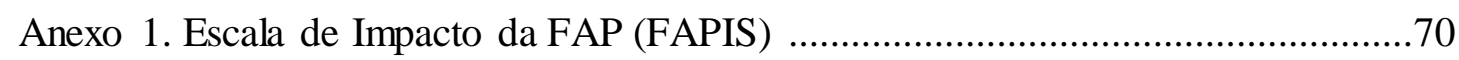

Anexo 2. Termo de consentimento livre e esclarecido - Cliente.................................73

Anexo 3. Termo de consentimento livre e esclarecido - terapeuta..............................77

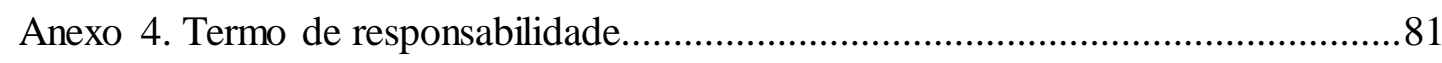




\section{LISTA DE ABREVIATURAS E SIGLAS}

CCR1 - Comportamento Clinicamente Relevante 1 (problema em sessão)

CCR2 - Comportamento Clinicamente Relevante 2 (melhora em sessão)

CCR3 - Comportamento Clinicamente Relevante 3 (descrição em sessão de CCRs)

CPR - Cliente avança positivamente na sessão

CTR - Cliente foca na relação terapêutica

FAP - Psicoterapia Analítica Funcional

FAPIS - Functional Analytic Psychotherapy Impact Scale

FAPRS - Functional Analytic Psychotherapy Rating Scale

INF - Resposta ineficaz do terapeuta a CCRs

O1 - Comportamento Externo 1 (problema externo)

O2 - Comportamento Externo 2 (melhora externa)

SFAPRS - Versão para Supervisão de Functional Analytic Psychotherapy Rating

Scale

T1 - Comportamentos problema do terapeuta

T2 - Comportamentos de melhora do terapeuta

TPR - Avanço positivo do terapeuta em sessão

TRB1 - Terapeuta responde efetivamente ao CCR1

TRB2 - Terapeuta responde efetivamente ao CCR2

TTR - Terapeuta foca na relação terapêutica

VD - Variável dependente

VI - Variável independente 


\section{SUMÁRIO}

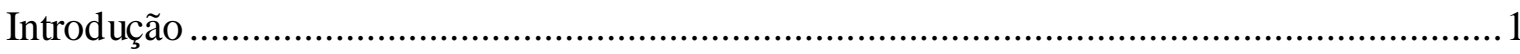

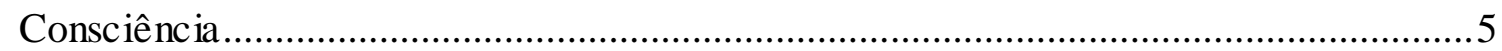

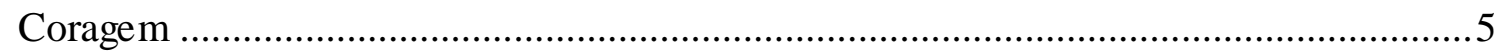

Amor

Treinos para formação de terapeutas em FAP ............................................................

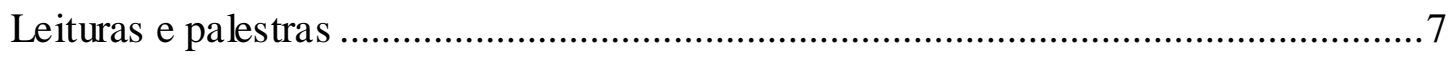

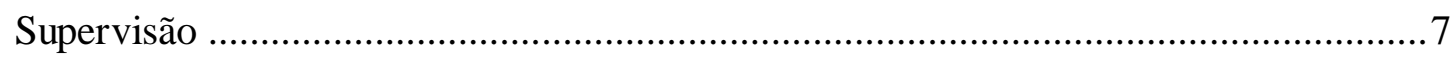

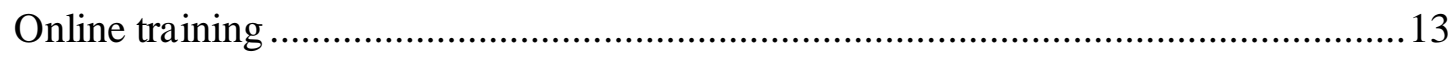

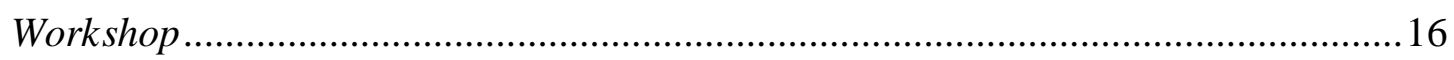

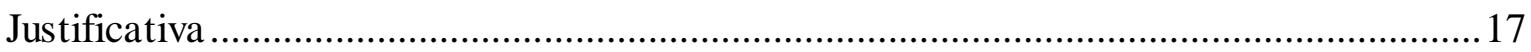

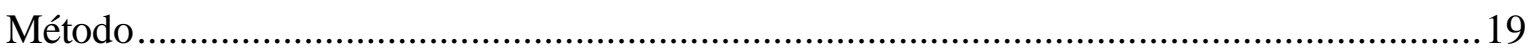

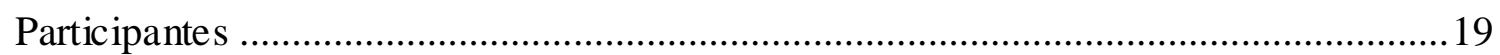

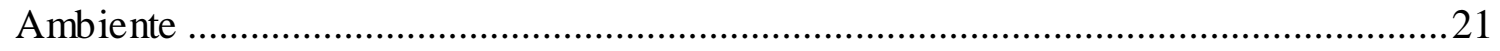

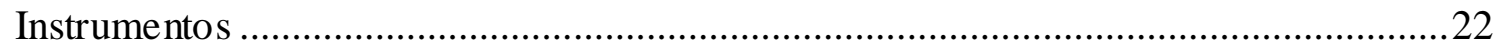

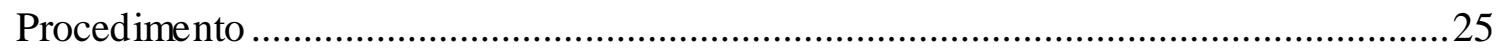

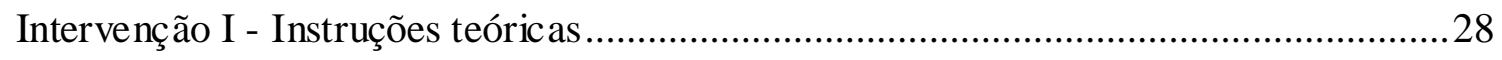

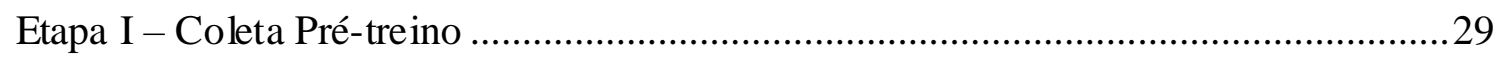

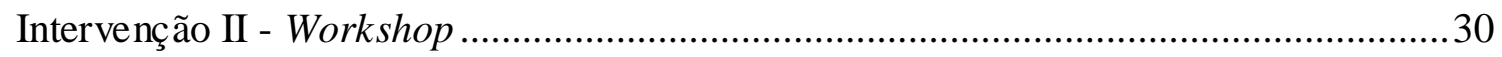

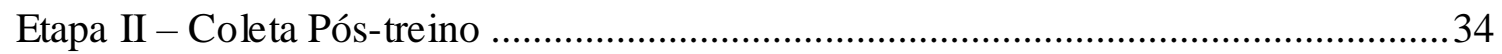

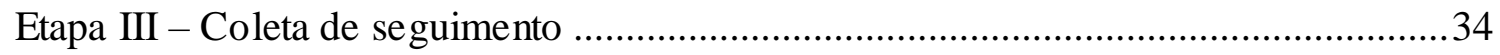

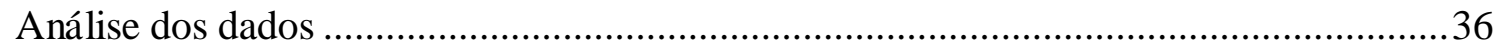




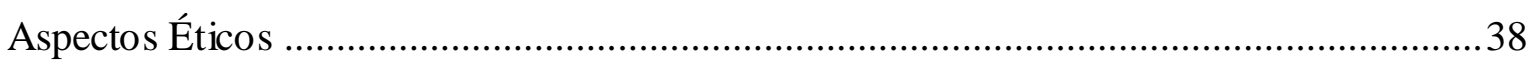

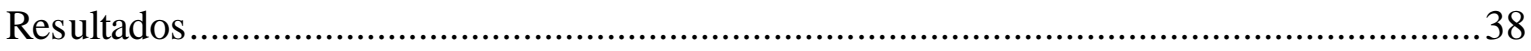

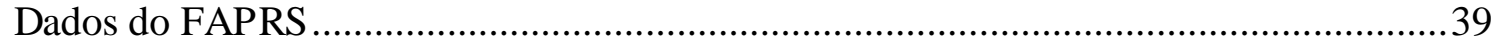

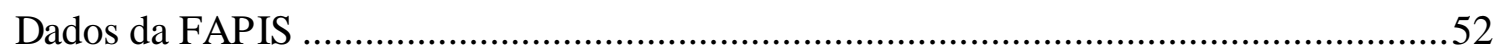

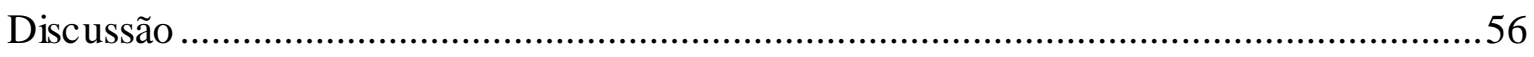

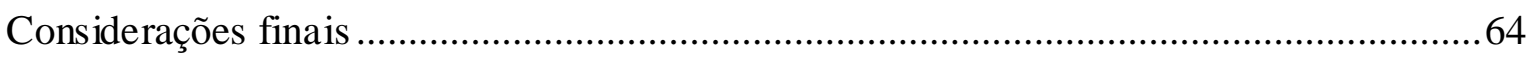

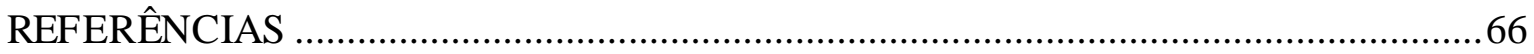

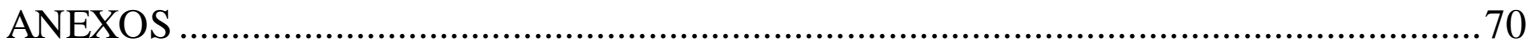




\section{EFEITOS DE WORKSHOP DE PSICOTERAPIA ANALÍTICA FUNCIONAL SOBRE HABILIDADES TERAPÊUTICAS}

\section{Introdução}

Segundo Holt-Lunstad, Smith, e Layton (2010), pessoas que têm relações sociais adequadas apresentam probabilidade $50 \%$ maior de sobrevivência em comparação com aqueles com relações sociais pobres ou insuficientes. A magnitude desse efeito é comparável a parar de fumar e é maior que fatores de risco de mortalidade bem estabelecidos, como sedentaris mo e obesidade. Sendo assim, intervenções voltadas para a melhoria das relações interpessoais têm importância não apenas para melhorar a qualidade de vida, mas para a sobrevivência.

Nesse sentido, Kohlenberg e Tsai (1991) desenvolveram uma terapia voltada para os problemas interpessoais dos clientes, que se vale da premissa de que os clientes apresentam em sessão os mesmos problemas interpessoais que ocorrem fora dela e que trazem prejuízos às relações e sofrimento ao cliente. Assim, o terapeuta se vale do que acontece na relação terapêutica para desenvolver repertórios interpessoais mais eficazes, de modo que o cliente consiga tornar suas relações mais próximas e íntimas.

Segundo Kohlenberg e Tsai (1991):

(...)(1) o único modo do terapeuta ajudar o cliente é por meio das funções reforçadoras, discriminativas e elic iadoras das ações do terapeuta, e que (2) estas funções de estímulo no decorrer da sessão exercerão seus maiores efeitos sobre o comportamento do cliente que ocorrer na própria sessão (p. 20).

Portanto, a Psicoterapia Analítica Funcional (FAP) tem seu foco voltado para comportamentos que ocorrem durante a sessão, para que possam ser observados diretamente pelo terapeuta e serem, portanto, passíveis de intervenção. Para tanto, os autores apontam três Comportamentos Clinicamente Relevantes (CCRs) e os denominam: CCR1 -problemas do cliente que ocorrem em sessão; CCR2 - progressos do cliente que ocorrem em sessão; CCR3 
- interpretações que o cliente faz sobre seu próprio comportamento e as variáveis que o controlam. A identificação desses comportamentos pode ser feita perguntando-se ao cliente sobre os problemas e interações positivas que ele tem nos relacionamentos do dia a dia, e como esses problemas se manifestariam no ambiente de sessão. A percepção do terapeuta sobre suas próprias reações ante o cliente, isso é, ante a maneira com a qual o cliente se relaciona com ele, também poderia convergir para outra forma de identificação de CCRs (Tsai, Callaghan \& Kohlenberg, 2013).

Para sistematizar a intervenção, Kohlenberg e Tsai (1991) desenvolveram cinco regras para orientar a prática do terapeuta. O seguimento das regras, lembram os autores, não se dá de forma rígida, mas se tratam de sugestões ao terapeuta que visam obter efeitos reforçadores para seus comportamentos. Na prática, as regras não são necessariamente seguidas nessa ordem, elas se misturam e muitas vezes são usadas simultaneamente. São elas:

Regra 1 - Atentar-se aos CCRs.

Trata-se do cerne da FAP, voltada à detecção dos CCRs especialmente em situações terapêuticas que frequentemente evocam CCRs, como: manifestações de afeto do cliente, eventos inusitados, silêncios e lapsos na conversa, entre outros.

Regra 2 - Evocar CCRs.

Uma vez estabelecidas a relação terapêutica e a conceituação de caso, os terapeutas devem estruturar as sessões para evocar CCRs, utilizar métodos terapêuticos evocativos e utilizar seu potencial como agente de mudança. A evocação dos comportamentos clinicamente relevantes do cliente é fundamental para possibilitar a modelage $\mathrm{m}$ de seus comportamentos-alvo.

Regra 3 - Prover consequências aos CCRs.

Preconizando o reforçamento como mecanismo primário de mudança, essa regra orienta os terapeutas para que provejam consequências reforçadoras naturais, sendo éticos, genuínos e 
agindo no melhor interesse do cliente, abordando ou bloqueando um CCR1 ou provendo consequências reforçadoras ao CCR2.

Regra 4 - Observar os efeitos potencialmente reforçadores do comportamento do terapeuta em relação aos CCRs do cliente.

Os terapeutas devem avaliar se e o quanto o seu comportamento foi realmente reforçador, atentando-se à função do próprio comportamento, e assim, graduar sua resposta para o melhor aproveitamento do potencial do reforçamento.

Regra 5 - Fornecer interpretações sobre as variáveis que controlam o comportamento do cliente e implementação de estratégias de generalização.

Os terapeutas devem auxiliar o cliente a discriminar as variáveis que controlam o seu comportamento e a generalizar os progressos da terapia para o seu cotidiano. Para isso, eles podem traçar paralelos entre comportamentos na sessão e no cotidiano do cliente e atribuir tarefas para que o cliente tente transpor um CCR2 para sua vida diária.

Callaghan (2006) aponta que as intervenções em FAP valem-se das mesmas proposições do behaviorismo radical, pois têm como mecanismo de mudança a modelagem ao vivo do repertório do cliente por meio de respostas do terapeuta contingentes aos comportamentos de problema e de melhora, enquanto eles ocorrem durante a sessão.

Follette e Batten (2000) afirmam que o foco da FAP é criar relações intensas na terapia, que seriam determinantes para a melhora do cliente. Para o desenvolvimento dessas relações, as emoções e o afeto têm papel central, pois é por meio da expressão das emoções que o terapeuta evoca e responde aos CCRs. Os autores sugerem que terapeutas podem não ser efetivos na implementação da FAP quando apresentam dificuldades em áreas semelhantes às relacionadas às queixas do cliente. Em outras palavras, o autoconhecimento do terapeuta lhe proporcionaria melhores condições para reagir com empatia em relação aos clientes, o que torna maior a importância do autoconhecimento do terapeuta. Porém, lidar com emoções e 
processos relacionados a elas é um repertório adquirido. Muito se tem estudado sobre formas de treino de terapeutas FAP para adquirir e utilizar este repertório durante seus atendimentos.

Com ênfase na vivência experiencial, outras formas de treino têm sido estudadas, como em um estudo realizado por Machado, Beutler e Greenberg (1999), que tinha como um dos objetivos o de determinar a existência de relação entre a atenção dos terapeutas às próprias emoções e a precisão em identificar os tipos e níveis de emoções nos clientes. Outro objetivo do estudo consistiu em identificar se o nível de experiência influencia no reconhecimento das emoções.

Os autores utilizaram um delineamento fatorial $2 \times 3$ no qual as variáveis independentes eram dois níveis de experiência dos participantes (estudantes de pós-graduação e terapeutas formados) e três condições de estímulos que variaram em complexidade de dicas emocionais verbais e não verbais. As variáveis dependentes incluíram precisão na identificação da qualidade emocional (reconhecimento da emoção presente, por exemplo) e intensidade emocional.

Os participantes deveriam avaliar as emoções expressas por um cliente de terapia por meio de partes de uma sessão de terapia gravada em vídeo e transcrita. A qualidade da avaliação foi medida por escala desenvolvida pelos próprios autores. Os resultados indicaram que maiores níveis de treinamento do terapeuta estavam associados à maior precisão em identificar as emoções dos clientes, além de demonstrar uma relação positiva entre atenção às emoções pessoais e a precisão em identificar a emoção no cliente. Com esse estudo, pode-se supor que a habilidade de reconhecer as próprias emoções tem impacto na habilidade em observar e reconhecer as emoções do cliente, o que está relacionado à primeira regra da FAP, a de atentar-se aos comportamentos clinicamente relevantes do cliente.

Segundo Tsai et al. (2009), é necessário que o terapeuta FAP esteja em contato com seus próprios sentimentos durante a sessão e que seja capaz de perceber seu impacto no 
cliente, o que requer uma habilidade diferente do conhecimento intelectual. Essas habilidades são necessárias para a aplicação das quatro primeiras regras citadas acima e atualmente estão relacionadas aos termos Consciência (Regras 1 e 4), Coragem (Regra 2) e Amor (Regra 3). Esses termos constituem o modelo de conexão social da FAP. Os autores desenvolveram esse modelo e esses termos para propiciar uma melhor compreensão dos objetivos da terapia FAP tanto para o cliente quanto para o terapeuta, objetivos esses que podem estar relacionados a quase todos os comportamentos do cliente que ocorrem em sessão (Haworth et al. 2015). Eles são melhor descritos a seguir:

\section{Consciência}

Trata-se de observar e estar atento ao cliente e também a si mesmo durante a sessão, habilidade importante para que o processo terapêutico tenha início e para que o terapeuta possa formular a conceituação de caso e determinar o foco da intervenção. Em outras palavras, significa estar atento ao que acontece e o que funciona em contextos interpessoais, identificando o impacto causado no outro em uma relação interpessoal, tanto para o terapeuta quanto para o cliente. A consciência envolve também o autoconhecimento do terapeuta, o que melhora sua capacidade de identificar as reações do cliente.

\section{Coragem}

Esse termo diz respeito ao engajamento em comportamentos interpessoais cujas consequências podem ser múltiplas e concorrentes, sendo algumas delas possivelmente aversivas, mas são comportamentos importantes para o estabelecimento e melhoria de relações sociais, que promovem aproximação, confiança, entre outros. Tanto para terapeuta quanto para o cliente, envolve lidar com o medo frente à possibilidade de punição. Para o terapeuta, envolve lidar com a dificuldade de evocar comportamentos clinicamente relevantes, que podem envolver bloquear esquivas emocionais do cliente relacionadas à terapia e ao 
próprio terapeuta, e falar sobre a relação terapêutica, o que normalmente requer maior exposição do terapeuta (p. ex., o terapeuta revelar o que está sentindo frente a determinado comportamento do cliente; quando o terapeuta propõe ao cliente discutir um assunto difícil; ou ainda, quando bloqueia uma esquiva - respostas passíveis de punição pelo cliente). Para o cliente, envolve lidar com a dificuldade de emitir comportamentos novos e que não fazem parte de seu repertório ou existem, mas não estão ainda bem estabelecido (por ex., por ter sido punido no passado). Pode incluir respostas como pedir atenção ou cuidado do terapeuta fora da sessão, no qual o risco seria a negativa do terapeuta, mas a consequência importante para a relação seria a aproximação de ambos e fortalecimento da relação terapêutica.

Comportamentos corajosos nesse sentido, embora possam ter consequências aversivas, visam trazer consequências reforçadoras positivas importantes em relacionamentos interpessoais.

\section{Amor}

Os autores da FAP defendem que se deve recorrer ao reforçamento natural na terapia, que se assemelha a relações genuínas e de cuidado com o cliente, em detrimento de reforçamento artificial, ou seja, reforçadores arbitrários como afirmações de aprovação ("Está bom"), por exemplo. Trata-se de ser terapeuticamente amoroso ao consequenciar os CCRs do cliente, de forma ética, genuína e sempre tendo como objetivo a melhora do cliente. $\mathrm{O}$ terapeuta amoroso preocupa-se e cuida das necessidades e sentimentos do cliente. Para o cliente, trata-se de ser amoroso consigo e com pessoas próximas, a fim de respeitar seus limites, promover autocuidado, e também de fortalecer e melhorar a qualidade de suas relações interpessoais. 


\section{Treinos para formação de terapeutas em FAP}

\section{Leituras e palestras}

Essa formação é a primeira a que normalmente os terapeutas recorrem. Não foram encontrados estudos sobre o treino instrucional/teórico de terapeutas. No entanto, mesmo para treinos práticos, o conhecimento teórico da FAP é imprescindível para sua aplicação.

\section{Supervisão}

Uma forma possível de treino de terapeutas ocorre por meio de supervisões. Na FAP, a supervisão permite ao terapeuta exercitar habilidades essenciais ao seu desempenho e ampliar sua base de conhecimentos. O supervisionando deve ser capaz de desenvolver uma formulação de caso para constatar quais comportamentos do cliente podem ser considerados como CCRs1 ou CCRs2. Além disso, ele deve evocar e reforçar naturalmente CCRs e realizar uma análise funcional sobre seus próprios comportamentos-problema enquanto terapeutas (T1s) e sobre seus comportamentos-alvo enquanto terapeutas (T2s), comportamentos estes que ocorrem durante seus atendimentos e em supervisão. Destacam-se ainda da supervisão FAP outros dois objetivos: desenvolver a flexibilidade, para que os terapeutas sejam capazes de analisar o efeito de suas respostas sobre o cliente e, então, adaptar suas estratégias conforme essa análise; e prover o conhecimento emocional do terapeuta, o que é determinante para sua capacidade de percepção, evocação e fortalecimento dos CCRs, e para que ele possa fazê-lo de forma autêntica e verdadeira (Tsai et al., 2009).

Essa forma de treino se dá de forma não apenas didática, mas experiencial, com foco nas habilidades clínicas do terapeuta, como as de intimidade, vulnerabilidade, exposição, entre outros (Kohlenberg \& Tsai, 1991). Nela, os alunos identificam seus comportamentos "problema" (T1) e seus comportamentos de melhora (T2) enquanto terapeutas. O supervisor se vale da identificação desses comportamentos para modelá-los em supervisão e então incentivar os alunos a emiti-los em sessão. 
Um dos estudos sobre supervisão FAP foi realizado por Sousa e Vandenberghe (2007). Os autores exploraram a possibilidade de aplicação dos princípios da FAP durante a supervisão de terape utas que atendiam clientes com Transtorno de Personalidade Borderline. A primeira autora conduziu supervisões individuais de quatro terapeutas com periodicidade mensal. Primeiramente, foram realizadas entrevistas semiestruturadas com os participantes para identificar a forma como as terapeutas se sentiam em relação aos CCRs dos clientes, bem como a forma como estavam lidando com esses sentimentos. Nas entrevistas, a autora identificou comportamentos das terapeutas referentes à supervisora ou à situação de supervisão que foram considerados relevantes na relação das mesmas com os clientes. A autora denominou estes comportamentos como Comportamentos Relevantes para a Terapia (CTR), logo, como comportamentos do terapeuta relevantes no contexto de supervisão em paralelo ao CCR do cliente em sessão. Da atuação das terapeutas, foram alvos de intervenção FAP os seguintes comportamentos: "dar razões e esquiva experiencial", que se referem à esquiva de encobertos aversivos e dificuldade em discriminar variáveis de controle do próprio comportamento, e "desespero", caracterizado por comportamentos de alta intensidade, que produzem consequências reforçadoras. Os autores observaram que os comportamentos das terapeutas estavam sob controle de amplo contexto, incluindo elementos de suas histórias pessoais, e levavam comportamentos da própria história de aprendizagem para os atendimentos terapêuticos, o que poderia impedir ou diminuir o progresso do cliente. Assim, as dificuldades que emergiram da relação entre a supervisora e as terapeutas tornaram-se oportunidades para a modelagem ao vivo dos comportamentos na tentativa de enfraquecê-los e de produzir repertórios mais produtivos, utilizando, portanto, as intervenções FAP no contexto da supervisão.

Embora, nas sessões, as terapeutas tenham tentado emitir novos comportamentos que foram modelados em supervisão, os clientes apresentaram consequências diferentes daquelas 
providas pela supervisora, punindo-os, o que as desencorajou a persistirem com as mudanças. Dessa forma, apesar de os autores terem declarado que os comportamentos em supervisão tenham sido modelados pela supervisora, não há clareza sobre o quanto houve de modelagem ou de controle por regras, pois nesse contexto não há manipulação precisa das variáveis que podem ter controlado os comportamentos das terapeutas, dado que não se trata de um procedimento experimental. De qualquer modo, essa forma usual de supervisão, com regras e com modelagem, não foi capaz de produzir as mudanças esperadas pela supervisora.

Um estudo observacional conduzido por Lepienski (2015) procurou avaliar o efeito de supervisões FAP sobre os comportamentos do terapeuta supervisionado e de seu cliente. Para isso, analisou e comparou dados de oito sessões de supervisão e de 12 sessões de atendimento, utilizando como instrumentos o FAPRS (Functional Analytic Psychotherapy Rating Scale), uma adaptação do mesmo instrumento para supervisões (SFAPRS - versão para Supervisão de Functional Analytic Psychotherapy Rating Scale) e outro instrumento desenvolvido pelo autor para esse estudo, que avaliou os Códigos de Comportamentos Relevantes do Terapeuta (CCRT).

Com início após a quarta sessão, as supervisões foram conduzidas por uma terapeuta com experiência em supervisão e com atendimento clínico com uso da FAP e foram voltadas para discussão de caso e também para intervenção em comportamentos da terapeuta. Os dados mostraram que, após o início das supervisões, a terapeuta passou a emitir em seus atendimentos menos respostas inadequadas (T1), de acordo com o instrumento desenvolvido pelo autor) e aumentou a aderência (seguimento das regras) à FAP. Observou-se, assim, melhora na emissão de TRBs1, mas não de TRBs2, permitindo concluir que a supervisão teve maior efeito nos comportamentos inadequados da terapeuta (T1) e na habilidade dela em prover consequências (TRB1) aos comportamentos "problema" do cliente em sessão do que na habilidade da terapeuta em prover consequências aos comportamentos de melhora (TRB2) 
- o que não contribuiu para o aumento das emissões de comportamento de melhora do cliente em sessão (CCR2).

No entanto, os dados mostram também que a condução da supervisão teve foco maior em estratégias não relacionadas à FAP em todas as sessões, o que pode ter contribuído para a melhora apenas parcial dos comportamentos da terapeuta. Além disso, o estudo não contou com um delineamento experimental com manipulação de variáveis, o que enfraquece a atribuição do efeito observado à supervisão. Utilizar um delineamento de sujeito único de reversão ou de linha de base múltipla nesse caso favoreceria inferências mais precisas.

Silveira et al. (2009) realizaram um estudo com o objetivo de investigar os efeitos de treino em FAP por meio de supervisões sobre a identificação pelo terapeuta de CCRs de um cliente. Nesse estudo, os autores selecionaram um estudante de graduação para participar como terapeuta e um cliente cuja queixa clínica principal se referia a dificuldades interpessoais. Foram realizadas quinze sessões de atendimento, cada uma delas seguida por uma supervisão de 50 minutos conduzida por uma terapeuta com experiência em FAP após o intervalo de um ou dois dias a partir da realização do atendimento. Da primeira à quinta sessão, as supervisões foram voltadas para a obtenção de dados de identificação sobre o cliente, da queixa, do histórico de vida e para a formulação do problema clínico e análise funcional dos comportamentos do cliente. Após a quinta sessão, a supervisão foi conduzida com foco em FAP, incluindo a explicação sobre o que eram os CCRs, discussão sobre os CCRs do cliente e modelagem pelo supervisor de comportamentos interpessoais do terapeuta relevantes para a terapia, além de ter sido solicitado ao terapeuta que lesse dois capítulos iniciais do livro Psicoterapia Analítica Funcional (Kohlenberg \& Tsai, 1991). Uma terapeuta com treino em FAP e a supervisora se revezaram como observadoras, assistindo às sessões através de um espelho unidirecional e realizaram registros de CCRs do cliente. O terapeuta também fazia registros dos CCRs de cada sessão, o que não foi discutido ou abordado durante 
as supervisões, para não enviesar esses dados. Estudantes de Psicologia foram colaboradores do estudo, e eles compararam as anotações feitas pela observadora e pelo terapeuta.

Os resultados mostraram que o terapeuta sem treinamento indicava diversos comportamentos irrelevantes como CCRs1, enquanto a observadora registrava consideravelmente menos emissões de CCRs1. Após a introdução do treino em FAP, o terapeuta passou a indicar mais CCRs2 de seu cliente, além de ter passado a emitir mais verbalizações de autoconhecimento. Os autores concluíram que o treino pôde melhorar a capacidade do terapeuta de identificar os CCRs de seu cliente, o que está relacionado à Regra 1 da FAP e, portanto, faz-se importante para o processo terapêutico.

Contudo, o estudo de Silveira et al. (2009) teve como objetivo observar o impacto da supervisão sobre o comportamento do terapeuta de relatar os CCRs de seu cliente, o que se enquadra na primeira regra da FAP, sendo indeterminado o impacto que o treino teve com relação à implementação das outras quatro regras da FAP por parte do terapeuta, bem como o impacto para o cliente, ou seja, se esse passou a emitir mais CCRs2 após o treino, por exemplo. Os autores afirmam que o instrumento FAPRS (Callaghan, Follette \& Linnerooth, 2008) ainda não havia sido validado e que este poderia aperfeiçoar a coleta de dados e responder a novas questões. Maiores informações sobre o instrumento constam na seção de método deste trabalho.

Wielenska e Oshiro (2012) também relataram a condução de supervisões FAP na Universidade de São Paulo para estudantes do curso de especialização em Terapia Cognitiva e Comportamental. As supervisões fizeram parte do curso intitulado "Terapia Cognitiva e Comportamental: Teoria e Prática”, e ocorreram no ano de 2010, uma vez por semana, em um grupo de catorze estudantes, sendo sete duplas, e a segunda autora como supervisora. Nenhum estudante tinha experiência de supervisão em FAP, embora tivessem algum conhecimento da teoria. As autoras consideraram a premissa de que as interações que ocorrem na supervisão, 
assim como na terapia e em contextos interpessoais diversos, evocarão alguns comportamentos-problema dos terapeutas supervisionados dando a oportunidade à supervisora de modelar esses comportamentos, respondendo a eles à medida que aparecerem.

O primeiro encontro começou com uma explicação sobre como as supervisões seriam conduzidas. Os alunos também foram orientados a se atentar aos relatos de problemas ocorridos fora de sessão (Os1) e CCRs1 do cliente, e foram alertados a respeito da possibilidade de serem evocados problemas e dificuldades dos terapeutas durante as sessões, sendo importante reportar isso durante a supervisão. Coube ainda à supervisora ensinar as regras da FAP para os terapeutas e explicar que o objetivo da supervisão era de ensiná-los a se atentar ao que acontece em sessão e a responderem às mudanças. E a forma como aprenderiam a fazê-lo seria durante a supervisão por meio de exposição direta a uma relação interpessoal intensa com a supervisora.

As autoras citam um relato que pode exemplificar a forma como se deu a relação da supervisora com os alunos: um cliente mudava de assunto frequentemente, aumentava seu tom de voz, perguntava sobre a vida dos terapeutas, evitando dessa forma falar sobre seus sentimentos e suas relações interpessoais. Na supervisão, os terapeutas que o atendiam apresentaram hipóteses sobre contingências externas à sessão que poderiam ser responsáveis por tais comportamentos do cliente. Percebendo que eles estavam evitando falar sobre que estava acontecendo na sessão, a supervisora descreveu a eles sua percepção e os questionou sobre como ela os fazia se sentirem durante a supervisão, fazendo um paralelo do que estava acontecendo na supervisão e o que acontecia nos atendimentos. Os terapeutas admitiram que estavam receosos quanto ao que a supervisora poderia pensar sobre o fato de não impedirem esses comportamentos da cliente. Afirmaram ter dificuldades para se aproximarem da cliente (embora percebessem essa necessidade) devido ao receio de que ela fizesse perguntas sobre a vida deles. Os terapeutas compartilharam ainda outros sentimentos e pensamentos difíceis que 
estavam ocorrendo. Frente a isso, a supervisora validou esses sentimentos e procurou reforçar essa autorrevelação dos terapeutas. Segundo as autoras, os terapeutas conseguiram atender novamente sem evitar possíveis tensões emocionais na terapia.

Outro repertório importante aprendido pelos alunos foi o de observar o impacto de seus comportamentos no outro. As autoras relatam que, durante o ano de supervisão, várias outras interações importantes como essa aconteceram entre a supervisora e os supervisionandos, que ocasionaram mudanças relevantes na forma como eles conduziam os atendimentos. A supervisora pôde notar que os alunos aprenderam a nomear seus sentimentos e a usá-los como possíveis pistas sobre o que estaria ocorrendo em sessão, e também a identificar, evocar e modelar CCRs. Outro aspecto observado indiretamente foi a diminuição da emissão de CCRs1 e aumento na frequência de emissão de CCRs2 por parte dos clientes, apesar de não terem sido usados instrumentos para medir tais resultados.

Em ambos os estudos (Silveira et al., 2009; Wielenska \& Oshiro, 2012), as supervisoras modelaram o repertório de autoconhecimento dos terapeutas e observaram neles melhoras na habilidade de identificar CCRs dos clientes, corroborando com Brandão (1999), para a qual as terapeutas que têm essa habilidade pouco desenvolvida podem ter dificuldades em identificar CCRs do cliente.

\section{Online training}

Com o objetivo de se treinar diretamente a exposição emocional, Kanter, Tsai, Holman e Koerner (2013) desenvolveram mais recentemente uma maneira de fazer o treinamento, realizado por meio de videoconferências e com a duração de duas horas semanais ao longo de oito semanas, e realizaram um estudo para verificar os efeitos do treino em FAP por meio de um workshop online. Para tanto, 16 terapeutas participaram da pesquisa e foram distribuídos randomic amente entre do is grupos, sendo um grupo o de treino imediato (Grupo 1) e outro de 
lista de espera para o treino (Grupo 2). Cada sessão de treino foi conduzida por dois treinadores. A primeira etapa do procedimento consistiu no de pré-treino dos participantes, em que todos eles (Grupos 1 e 2) receberam um e-mail duas semanas antes do início do workshop online que explicava a racional do mesmo e contendo um exercício no qual os participantes deveriam escrever um breve resumo de sua história de vida. Além disso, os terapeutas participantes deveriam indicar aos treinadores qualquer outra informação útil e expressar, caso tivessem a intenção e o desejo de assumir riscos interpessoais (comportamentos-alvo difíceis de serem emitidos pelos participantes) durante o grupo para que, assim, os treinadores pudessem encorajá-los apropriadamente, a depender de seus objetivos.

As videoconferências aconteceram em uma plataforma online apropriada para este fim, com recurso de áudio, vídeo e mensagens instantâneas. A segunda etapa do procedimento consistiu na realização do workshop online, do qual participou o Grupo 1. Vários exercícios foram conduzidos nos quais os terapeutas participantes deveriam emitir comportamentos corajosos e amorosos, de acordo com o modelo ACL. Nas três primeiras sessões de treino, por exemplo, os treinadores requereram a cada participante que compartilhasse sua autobiografia ao grupo durante seis a oito minutos e os encorajaram a assumir riscos relacionados à expressão emocional e à honestidade (ou seja, encorajaram a emitir prováveis CCR2). Ao fim de cada apresentação de autobiografia, cada participante, incluindo os treinadores, tinha 30 segundos para prover umfeedback ou reflexão como forma de praticar o reforçar natural do CCR2. Embora os participantes estivessem respondendo uns aos outros, os treinadores poderiam modelar o responder e prover feedbacks adicionais. Os participantes foram, então, encorajados a emitir comportamentos de assumir riscos interpessoais, a prover reflexões com outras pessoas, incluindo seus clientes, e a registrar e relatar estes comportamentos no começo da próxima sessão. 
Outros exercícios incluíram feedback dos registros realizados pelos participantes sobre os CCR2 emitidos e discussão sobre temas normalmente evitados. Breves apresentações didáticas também foram utilizadas para que os participantes tivessem mais conhecimento teórico sobre conceitos behavioristas e de FAP. Foram usados como instrumentos de medida a FAP Impact Scale (FAPIS), um questionário de avaliação do treino e Vinhetas FAP. As Vinhetas FAP foram desenvolvidas para esse estudo como forma de registrar o impacto desse treino nas respostas escritas pelos terapeutas sobre situações hipotéticas de terapia. O objetivo do instrumento FAPIS é o de avaliar o impacto do treino nos participantes e consiste numa escala de auto avaliação com 46 itens. A análise qualitativa do instrumento indicou que este avalia diversas habilidades pertinentes à FAP, incluindo autoconsciência, consciência do cliente, coragem, amor terapêutico (reforçamento), valores, autorrevelação, competência behaviorista e foco em sessão.

Antes do início do workshop, foram aplicados a FAPIS e as vinhetas para ambos os grupos, e após o workshop ambas foram aplicadas novamente para os dois grupos e também o questionário de avaliação do curso para o grupo experimental. Em seguida, o Grupo 2 participou do workshop online e, posteriormente, foram aplicados novamente os mesmos instrumentos. A análise estatística com a medida ANOVA dos resultados comparativos pré e pós-treino dos instrumentos FAPIS e Vinhetas FAP mostrou que o treino teve efeito estatisticamente significativo em ambos os grupos, não sendo observadas diferenças relevantes entre os grupos, um indicativo de que o efeito resultou treino e não da passagem do tempo. O feedback qualitativo provido pelos participantes sobre o curso foi consistente com os resultados dos instrumentos de medida e sugerem que os terapeutas participantes ficaram muito satisfeitos com o treino por perceberem ter alcançado uma considerável melhora, especificamente naquelas habilidades que foram alvo de intervenção no workshop, entre elas, a capacidade de se conectar intimamente a outras pessoas e a de se arriscar emocionalmente 
(emitir CCR2s relacionados à expressão emocional) e a capacidade melhorada de se engajar em relações terapêuticas intensas e próximas.

Ainda que os resultados tenham sido muito positivos, os autores destacam que os participantes já haviam participado de um workshop presencial e tinham interesse considerável em FAP, portanto, os resultados podem não ser generalizáveis, o que torna importante replicar esse estudo com terapeutas com diferentes níveis de motivação quanto à FAP. Acrescenta-se ainda, a inexistência de medidas indicativas de que estas melhoras relatadas pelos participantes sejam condizentes com o comportamento deles enquanto terapeutas durante sessões. A escassez de produção acadêmica a respeito desse tipo de treino confere bastante importância a esse estudo. Como contraponto, cabe apontar que o estudo apresenta apenas dados preliminares, não realizando, por exemplo, um seguimento para verificar a manutenção das mudanças verificadas. Outro ponto a se considerar nesse estudo diz respeito ao fato de o treino ter sido conduzido por Mavis Tsai, autora que desenvolveu a FAP. Seria pertinente, portanto, verificar se tais resultados seriam também obtidos com a aplicação do treino por outros terapeutas.

\section{Workshop}

Os workshops FAP começaram a ser desenvolvidos durante os anos de 1995 a 2002, por Robert Kohlenberg e seus estudantes de pós-graduação. Tinham um formato didático e, desse modo, os desenvolvedores não estavam completamente satisfeitos com a forma como se davam os treinamentos; estavam, sim, interessados em uma maneira de realizar análises funcionais, identificando CCRs1 e 2 dos participantes enquanto terapeutas, para realizar modelagem durante o workshop. Ao mesmo tempo, Mavis Tsai estava formulando um treino com seus estudantes de pós-graduação, que consistia em um curso com o formato de terapia FAP em grupo. Nesse curso, ela criou diversos exercícios que atualmente são comuns em 
treinos em FAP. A partir de sua realização no formato original, ela adaptou esse curso para uma versão online com duração de oito semanas, o que possibilita o treino de pessoas em qualquer parte do mundo. Tsai desenvolveu ainda uma versão de dois dias de workshop, na qual os participantes foram tratados como clientes, sendo propostos a eles vários exercícios com pouca quantidade de conteúdo didático, em sua maioria experiencial. A autora começou a usar o termo ACL - sigla em inglês para Consciência, Coragem e Amor - para descrever o que estava acontecendo nesses cursos, por volta de 2007. Os exercícios utilizados nos workshops variam e continuam em constante mudança a fim de se alcançar um formato que contenha mais modelagem de CCRs2 e menos teoria sobre FAP (J. Kanter, comunicação pessoal, 12 de janeiro de 2015).

O workshop (melhor descrito na seção Método) tem por objetivo modelar o repertório do terapeuta como forma adicional aos estudos teóricos, revelando-se um ambiente no qual comportamentos desejáveis ao terapeuta FAP podem ser evocados e consequenciados de forma contingente e natural pelos participantes e ministrantes.

A oferta por workshops para treinamento de terapeutas em terapias de terceira geração vem crescendo no mundo, e tem se iniciado no Brasil com treinamentos em FAP desde 2011. Portanto, faz-se necessário que haja a verificação da eficácia deste tipo de treino. A hipótese aqui considerada é a de que o workshop possibilita ao terapeuta vivenciar novas formas de se relacionar com o outro, podendo obter, assim, a habilidade e o conhecimento necessários para a aplicação da FAP em sua prática clínica.

\section{Justificativa}

Retomando os estudos relativos às formas de treino em FAP apresentados na introdução, os principais aspectos deles podem ser sintetizados a seguir: 
A possibilidade de o terapeuta adquirir habilidades clínicas por meio da leitura de textos está vinculada a comportamentos que abrangem a capacidade de seguir regras. Nesse sentido, uma pessoa que segue regras ou conselhos pode não se comportar precisamente como alguém que tenha sido diretamente exposto a contingências (Skinner, 1982). Em outras palavras, o conhecimento teórico do terapeuta não necessariamente se traduz em habilidades práticas.

Segundo Tsai et al. (2009), essas habilidades práticas, necessárias para a implementação da FAP, podem ser aprendidas em supervisão por meio da "exposição direta a uma relação interpessoal intensa com o supervisor, na qual ocorrem a emissão e a observação de respostas emocionais importantes", sendo esse o componente experiencial desse modelo de supervisão. Embora a supervisão FAP envolva tanto a modelagem desses repertórios quanto instruções aos terapeutas sobre como agir na sessão (controle por regras), existe o risco de as instruções diretas ao terapeuta produzirem comportamentos rígidos, controlados por regras e, portanto, insuficientemente sensíveis às contingências presentes (Follette \& Callaghan, 1995).

Assim, o workshop pretende valer-se da mesma lógica, modelando esses repertórios diretamente com os terapeutas participantes.

Pelo fato de o treino se dar por modelagem direta dos comportamentos desejáveis ao terapeuta durante o workshop, supõem-se que a sua eficácia possa superar a dos cursos instrucionais, uma vez que os participantes estariam expostos à possibilidade de modelagem direta do comportamento-alvo, e não apenas às regras. Pode-se também supor que, se as intervenções do terapeuta forem mais efetivas em sessão, elas seriam reforçadas pela melhora do cliente. Desse modo, torna-se necessário verificar se essas hipóteses se confirmam no contexto do workshop.

Levando em consideração o que tem sido exposto, o objetivo do presente trabalho é o de verificar se o treino por meio de workshop em FAP, adicionalmente à instrução teórica, 
atinge seus objetivos, ou seja, instala no terapeuta repertórios relacionados ao envolvimento com o cliente e propicia o seguimento das regras da FAP ao longo de sessões de terapia, em comparação à instrução teórica, exclusivamente.

Os objetivos específicos desta pesquisa são de investigar se, após a exposição do terapeuta a instruções teóricas e workshop (variável independente), ocorrem mudanças no comportamento e no do seu cliente durante as sessões de terapia. Tal objetivo é medido pela frequência de:

1) Comportamentos do terapeuta relacionados às categorias do FAPRS (variável dependente), especialmente os relacionados às categorias Regra 2, TRB1 e TRB2.

2) Comportamentos do cliente de acordo com as categorias do FAPRS (variável dependente), especialmente os relacionados às categorias CCR1 e CCR2.

\section{Método}

\section{Participantes}

Terapeutas: Os terapeutas participantes deste estudo atenderam aos seguintes critérios: utilizam a abordagem comportamental em seus atendimentos; não participaram de nenhum treino específico ou experiencial sobre FAP, como workshops e cursos. A escolha dos critérios teve por objetivo garantir que os terapeutas tivessem alguma experiência clínica e conhecimento teórico sobre a abordagem comportamental, mas que não tivessem participado de treinos experienciais para utilizarem a FAP em seus atendimentos.

A variável independente, o workshop, foi introduzida em momentos distintos da coleta para os participantes P1 e P2. Ambos os participantes detinham previamente algum conhecimento teórico sobre FAP e foram instruídos a ler os dois 
capítulos descritos na seção Intervenção I. Posteriormente, eles participaram do workshop e, na sequência, a coleta continuou durante cinco sessões, que se somaram a outra de seguimento coletada cerca de três meses após a introdução da variável independente.

A Participante 1 (P1) é do gênero feminino, tinha 25 anos quando a coleta se iniciou e formou-se Psicóloga havia três anos. Ela possui formação em acompanhamento terapêutico e atendimento extra consultório e qualificação avançada em clínica analítico-comportamental. Durante o curso de qualificação avançada, a P1 teve contato com a teoria da FAP, porém, sem ter passado por treinamento específico em habilidades terapêuticas da FAP.

O Participante 2 (P2) é do gênero masculino, estava com 25 anos ao início da coleta e cursava o último ano de Psicologia. P1 realizou os atendimentos como parte dos requisitos de seu estágio clínico supervisionado em Análise do Comportamento, coletando os dados para a presente pesquisa nesses atendimentos. Outro requisito era o de frequentar as supervisões clínicas, sendo que estas continham FAP de forma assistemática.

Clientes: Segundo os critérios adotados, foram selecionados clientes adultos, que já estivessem sendo atendidos por terapeutas participantes, cuja queixa permeava dificuldades de relacionamento interpessoal. Os critérios visaram possibilitar a intervenção em FAP, que tem como foco de intervenção as dificuldades de relacionamento interpessoal.

A Cliente 1 (C1) tinha 32 anos, é do gênero feminino e as queixas abrangiam depressão e de problemas interpessoais. Ela estava em terapia havia 21 meses no início da coleta. 
O Cliente 2 (C2) é do gênero masculino, tem 21 anos e suas queixas incluíam insatisfação com o trabalho, pensamentos suicidas, ansiedade e de falta de contato com atividades que lhe são prazerosas. No início da coleta, ele se encontrava em terapia havia cerca de nove meses.

Treinadora: A treinadora que ministrou o workshop conta, como terapeuta, com mais de dez anos de experiência clínica, além de possuir certificação em FAP pela Universidade de Washington/EUA, além de possuir o título de doutora pelo Departamento de Psicologia Clínica da Universidade de São Paulo. Destaca-se, ainda, de seu trabalho, a investigação de processos da FAP responsáveis por aumentar a efetividade da melhora terapêutica. A treinadora participou de também dois workshops sobre FAP ministrados por Jonathan Kanter, de um online training denominado "How to Give and Get Feedback to Shape CCR", ministrado por Kelly Koerner e Gareth Holman, e do online training sobre FAP, liderado por Gareth Holman e Catherine McClafferty. Em conjunto com Jonathan Kanter, a treinadora co-liderou um workshop, auxiliando na condução de outros dois workshops, um ministrado por Mavist Tsai e Robert Kohlenberg e outro conduzido pelos mesmos, além de Jonathan Kanter. Ela também co-liderou um Online training com Gareth Holman e liderou o primeiro workshop sobre FAP ministrado em português, a partir do qual, viria a liderar subsequentemente outros cinco workshops no Brasil.

\section{Ambiente}

A P1 realizou os atendimentos em seu consultório particular, e o P2 realizou os atendimentos nas dependências da clínica-escola. 
As salas possibilitam que os atendimentos sejam conduzidos adequadamente e que o sigilo seja mantido. Todos realizaram gravações das sessões em áudio para viabilizar a transcrição das sessões. O workshop pelo qual os terapeutas passaram foi realizado em ambiente apropriado para este fim, contendo recursos de data show e com espaço e condições de privacidade adequados para a sua realização.

\section{Instrumentos}

Sistema de classificação da Psicoterapia Analítico Funcional (Functional Analytic Psychotherapy Rating Scale - FAPRS, Callaghan, Follette \& Linnerooth, 2008) adaptado:

Este instrumento foi desenvolvido para avaliar e categorizar gravações em áudio ou vídeo de sessões de psicoterapia conduzidas de acordo com os princípios da FAP, propiciando o registro e a documentação de mudanças de comportamentos de terapeutas e clientes. Para utilizá-lo, os autores apontam a necessidade de os avaliadores deterem conhecimento dos princípios da FAP e conhecimento básico de Análise do Comportamento. Seria recomendável, ainda, experiência com FAP por meio da aplicação na prática clínica e supervisões, e não apenas conhecimento teórico. Esses requerimentos e recomendações existem para aumentar a precisão na cate gorização dos comportamentos observados. Para a análise de comportamentos de clientes e de terapeutas são utilizados códigos que representam cada categoria. Os códigos usados para categorizar os comportamentos dos clientes estão apresentados na Tabela 1. A descrição mais precisa e detalhada de cada categoria encontram-se no manual do instrumento (Callaghan \& Follette, 2008). 
Tabela 1.

Códigos de comportamentos do cliente e descrição resumida

\begin{tabular}{|c|c|c|}
\hline Código & Nome da categoria & Descrição resumida \\
\hline CCR1 & $\begin{array}{l}\text { Comportamento Clinicamente } \\
\text { Relevante } 1 \text { (problema em sessão) }\end{array}$ & Cliente emite comportamento problema na sessão \\
\hline CCR2 & $\begin{array}{l}\text { Comportamento Clinicamente } \\
\text { Relevante } 2 \text { (melhora em sessão) }\end{array}$ & Emissão de comportamento de melhora em sessão \\
\hline CCR3 & $\begin{array}{l}\text { Comportamento Clinicamente } \\
\text { Relevante } 3 \text { (descrição em sessão } \\
\text { de CCRs) }\end{array}$ & $\begin{array}{l}\text { Cliente descreve relação funcional (pelo menos resposta- } \\
\text { consequência) relacionada aos CCRs trabalhados em } \\
\text { sessão }\end{array}$ \\
\hline $\mathbf{0 1}$ & $\begin{array}{l}\text { Comportamento Externo } 1 \\
\text { (problema externo) }\end{array}$ & $\begin{array}{l}\text { Cliente descreve ou discute comportamento problema } \\
\text { que ocorre fora da sessão }\end{array}$ \\
\hline $\mathbf{O 2}$ & $\begin{array}{l}\text { Comportamento Externo } 2 \\
\text { (melhora externa) }\end{array}$ & $\begin{array}{l}\text { Cliente descreve ou discute comportamento de melhora } \\
\text { que ocorre fora da sessão }\end{array}$ \\
\hline CTR & $\begin{array}{l}\text { Cliente foca na relação } \\
\text { terapêutica }\end{array}$ & $\begin{array}{l}\text { Cliente fala com foco na relação terapêutica. } \\
\text { Comportamento não é categorizável como CCR }\end{array}$ \\
\hline CPR & $\begin{array}{l}\text { Cliente avança positivamente na } \\
\text { sessão }\end{array}$ & $\begin{array}{l}\text { Cliente discute ou descreve problemas que ocorrem em } \\
\text { situações não relacionadas à relação terapêutica, ou } \\
\text { explica contexto sobre os problemas. Comportamento } \\
\text { não categorizável como outros códigos. }\end{array}$ \\
\hline
\end{tabular}

Os códigos usados para categorizar os comportamentos do terapeuta e suas descrições estão apresentados na Tabela 2. 
Tabela 2.

Códigos de comportamentos do terapeuta e descrição resumida

\begin{tabular}{|c|c|c|}
\hline Código & Nome da categoria & Descrição resumida \\
\hline Regra 1 & Terapeuta avalia CCRs & Terapeuta avalia os CCRs do cliente em sessão \\
\hline Regra 2 & Terapeuta evoca CCRs & $\begin{array}{l}\text { Terapeuta evoca, pede ou solicita diretamente } \\
\text { (verbalmente) um CCR. Independe do comportamento } \\
\text { do cliente que o segue }\end{array}$ \\
\hline TRB 1 & $\begin{array}{l}\text { Terapeuta responde } \\
\text { efetivamente ao CCR1 }\end{array}$ & $\begin{array}{l}\text { Terapeuta responde a comportamento problema do } \\
\text { cliente em sessão, incluindo a descrição de } \\
\text { sentimentos do terapeuta }\end{array}$ \\
\hline TRB2 & $\begin{array}{l}\text { Terapeuta responde } \\
\text { efetivamente ao CCR2 }\end{array}$ & $\begin{array}{l}\text { Terapeuta responde efetivamente a comportamento de } \\
\text { melhora do cliente em sessão, incluindo a descrição de } \\
\text { sentimentos do terapeuta }\end{array}$ \\
\hline INF & Resposta ineficaz a CCRs & $\begin{array}{l}\text { Terapeuta falha grosseiramente ao consequenciar } \\
\text { CCRs, reforçando um CCR1 ou punindo um CCR2 }\end{array}$ \\
\hline Regra 4 & $\begin{array}{l}\text { Terapeuta verifica o efeito do } \\
\text { seu responder }\end{array}$ & $\begin{array}{l}\text { Terapeuta refere-se ou pergunta sobre o efeito de sua } \\
\text { resposta sobre o comportamento do cliente }\end{array}$ \\
\hline Regra 5 & Terapeuta discute CCR3 ou O3 & $\begin{array}{l}\text { Terapeuta descreve aspectos funcionais do } \\
\text { comportamento do cliente em sessão, podendo incluir } \\
\text { paralelos sobre comportamentos do cliente dentro e } \\
\text { fora de sessão }\end{array}$ \\
\hline TTR & $\begin{array}{l}\text { Terapeuta foca na relação } \\
\text { terapêutica }\end{array}$ & $\begin{array}{l}\text { Terapeuta fala com foco na relação terapêutica. Não } \\
\text { categorizável com outro código }\end{array}$ \\
\hline TPR & $\begin{array}{c}\text { Avanço positivo do terapeuta } \\
\text { na sessão }\end{array}$ & $\begin{array}{l}\text { Terapeuta emite comportamentos efetivos ou } \\
\text { facilitadores sem foco em CCRs. Não categorizável } \\
\text { com outros códigos }\end{array}$ \\
\hline
\end{tabular}

Functional Analytic Psychotherapy Impact Scale (FAPIS) (Wetterneck, Lee \& Holman, 2016).

A FAPIS é uma escala likert de autorrelato de 46 itens que avalia o impacto em participantes de treinos em FAP. Ela aborda vários domínios relativos às 
competências de terapeutas FAP, como autoconsciência, consciência do cliente, coragem, amor terapêutico, valores, autorrevelação, competências analíticocomportamentais, e foco em sessão.

Essa versão ainda não havia sido validada até a utilização no presente estudo. Após a realização da coleta, os autores fizeram alterações na escala, resultando em duas versões: uma contendo 72 itens e a outra, uma versão reduzida com 33 itens. Um estudo preliminar de validação da escala foi realizado, porém, até conclusão desta pesquisa, os resultados não haviam sido publicados.

\section{Procedimento}

O delineamento adotado foi o de linha de base múltipla com comparação intrassujeitos. Nele, a condição experimental (variável independente - VI) é introduzida em sequência temporal para diferentes comportamentos, condições ou sujeitos. Há apenas uma linha de base e uma intervenção para cada participante, ou seja, não existe reversão. A principal vantagem desse delineamento consiste em poder excluir a passagem do tempo enquanto responsável por mudanças ocorridas, além do fato de ser apropriado para comportamentos aprendidos, de difícil reversão e que, portanto, não são passíveis de serem avaliados por um delineamento $\mathrm{ABAB}$ (Nock, Michel \& Photos, 2008).

No presente estudo, as variáveis dependentes mensuradas correspondem às cate gorias do instrumento FAPRS (Callaghan \& Follette, 2008, adaptado) relativas ao terapeuta e ao cliente e a VI foi o workshop.

Kratochwill et al. (2012) definiram critérios como padrões para pesquisas com delineamento de sujeito único, para tornar possível a verificação da validade interna desses estudos, dado que sua importância tem sido reconhecida para a lguns tipos de 
intervenção, especialmente para aquelas que visam o tratamento de problemas de baixa incidência. Para que os delineamentos de linha de base múltipla atendam aos padrões definidos pelos autores, eles devem incluir um mínimo de seis fases (ao menos três fases A e três fases B), sendo três linhas de base (três participantes), para a avaliação das variáveis dependentes anteriores à intervenção (workshop), e três fases experimentais após a intervenção com ao menos cinco pontos de coleta de dados por fase. Os autores consideram que um estudo com seis fases e três a quatro pontos de coleta de dados atendem aos padrões com reservas, e quaisquer fases com menos de três pontos de coleta de dados não podem ser usadas para demonstração de efeito. Sendo assim, optou-se por abranger cinco pontos de coleta de dados em cada fase, para atender aos padrões definidos por Kratochwill et al. (2012) em relação a estudos de linha de base múltipla para haver demonstração de efeito da VI e validade interna. Embora se tenha pretendido cumprir o critério de três linhas de base, devido à perda de participantes ao longo da coleta, esse estudo se deu com apenas duas, ou seja, dois participantes.

Kazdin (2002) também afirma que duas linhas de base é o mínimo para a demonstração de efeito da variável independente, mas que uma ou duas a mais aumentam a força da demonstração. Supõe-se que o comportamento avaliado (VDs) não mude até a apresentação da VI. Caso ocorra, isso sugere que a intervenção pode não ser a determinante para o efeito.

Portanto, havia a previsão para quatro participantes com o objetivo de viabilizar três linhas de base em caso de desistência de algum deles. Contudo, devido às desistências ocorridas e a impossibilidade de transcrição em razão da má qualidade do áudio, foi possível manter apenas duas linhas de base distintas com duas díades participantes. 
A coleta de dados teve início em momentos diferentes da terapia para cada participante, de modo a possibilitar que a verificação de mudanças ocorresse após o workshop e não apenas com a evolução da terapia, isto é, os clientes já estavam em atendimento antes do início da coleta. As sessões foram transcritas e categorizadas com o instrumento FAPRS (Callaghan \& Follette, 2008) e buscou-se verificar a ocorrência de mudanças entre uma fase e outra nas categorias determinadas pelo instrumento. Uma sessão de seguimento foi transcrita e categorizada para que fosse viável verificar a manutenção de possíveis resultados da intervenção nos comportamentos dos clientes e terapeutas participantes após três meses de sua apresentação. A Figura 1 ilustra o procedimento previsto, no qual as sessões que seriam transcritas e categorizadas estão identificadas por " $\mathrm{X}$ ". As linhas verticais mostram a apresentação da instrução teórica e do workshop, que ocorreria em momentos diferentes da terapia para cada díade participante.

\begin{tabular}{|c|c|c|c|c|c|c|c|c|c|c|c|c|c|c|c|c|c|c|c|c|c|c|}
\hline \multicolumn{23}{|c|}{ Instrução teórica } \\
\hline $\begin{array}{c}\text { Semanas/ } \\
\text { Participantes }\end{array}$ & 1 & 2 & 3 & 4 & 5 & 6 & 7 & 8 & 9 & 10 & 11 & 12 & 13 & 14 & 15 & 16 & 17 & 18 & 19 & 20 & 22 & 27 \\
\hline Participante 1 & $X$ & $\mathrm{x}$ & $\mathrm{X}$ & $\mathrm{X}$ & $x$ & $\mathrm{X}$ & $\mathrm{X}$ & $\mathrm{X}$ & $\mathrm{X}$ & $\mathrm{X}$ & & & & & & & $\mathrm{X}^{*}$ & & & & & \\
\hline Participante 2 & $\mathrm{X}$ & & $\mathrm{X}$ & & $\mathrm{X}$ & & $\mathrm{X}$ & & $\mathrm{X}$ & & $\mathrm{X}$ & $\mathrm{X}$ & $\mathrm{X}$ & $\mathrm{X}$ & $\mathrm{X}$ & & & & & & $\mathrm{X}^{*}$ & \\
\hline Participante 3 & & & $\mathrm{X}$ & & & $\mathrm{x}$ & & & $\mathrm{X}$ & & & $\mathrm{X}$ & & & $\mathrm{X}$ & $\mathrm{X}$ & $\mathrm{X}$ & $\mathrm{X}$ & $\mathrm{X}$ & $\mathrm{X}$ & & $\mathrm{X}^{*}$ \\
\hline
\end{tabular}

Figura 1. Delineamento experimental de linha de base múltipla, com as sessões em que haveria coleta de dados

Conforme informado anteriormente, não foi possível obter três linhas de base distintas, e a Figura 2 ilustra o delineamento ocorrido, diferente do previsto: 


Instrução teórica
\begin{tabular}{|l|c|c|c|c|c|c|c|c|c|c|c|c|c|c|c|c|c|}
\hline $\begin{array}{l}\text { Womanas/ } \\
\text { Participantes }\end{array}$ & 1 & 2 & 3 & 4 & 5 & 6 & 7 & 8 & 9 & 10 & 11 & 12 & 13 & 14 & 15 & 18 & 35 \\
\hline Participante 1 & $\mathrm{X}$ & $\mathrm{X}$ & $\mathrm{X}$ & $\mathrm{X}$ & $\mathrm{X}$ & $\mathrm{X}$ & $\mathrm{X}$ & $\mathrm{X}$ & $\mathrm{X}$ & $\mathrm{X}$ & & & & & & $\mathrm{X}^{*}$ & \\
\hline Participante 2 & & $\mathrm{X}$ & $\mathrm{X}$ & $\mathrm{X}$ & & $\mathrm{X}$ & & $\mathrm{X}$ & & & $\mathrm{X}$ & $\mathrm{X}$ & $\mathrm{X}$ & $\mathrm{X}$ & $\mathrm{X}$ & & $\mathrm{X}^{*}$ \\
\hline
\end{tabular}

Figura 2. Delineamento de linha de base múltipla com duas linhas de base, em que os pontos de coleta de dados estão identificados por X e o seguimento por $\mathrm{X}^{*}$.

É importante destacar que a Figura 2 ilustra o delineamento indicando que as linhas de base têm duração diferente uma da outra, pois a fase de coleta durou cinco sessões para a P1 e 10 sessões para o P2. No entanto, o workshop ocorreu no mesmo dia para ambos os participantes, sendo diferentes a duração da coleta e da terapia para cada participante e não o tempo cronológico. O procedimento está ilustrado conforme o ocorrido cronologicamente na Figura 3.

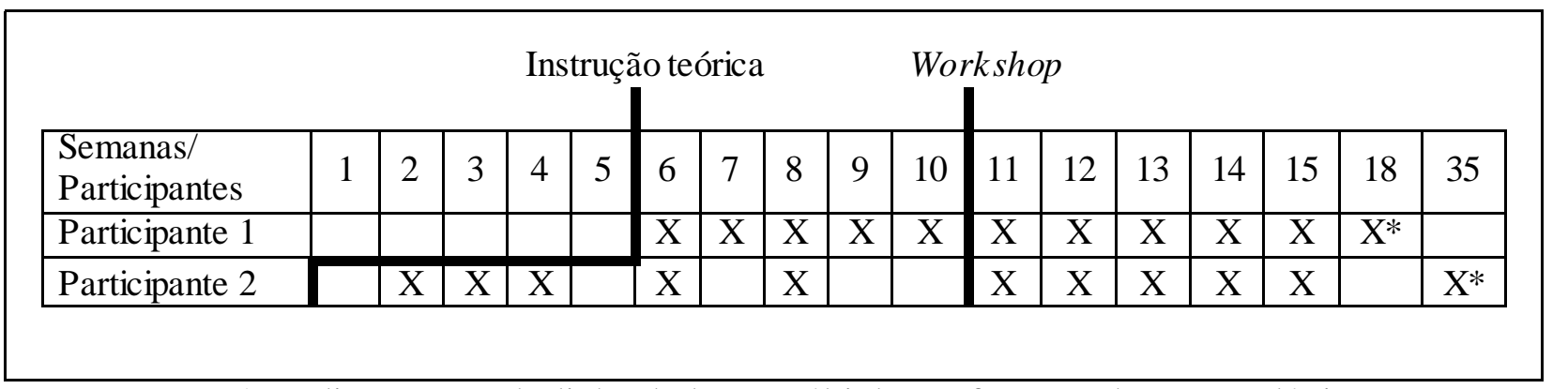

Figura 3. Delineamento de linha de base múltipla conforme ordem cronológica, em que os pontos de coleta de dados estão identificados por X e o seguimento por $\mathrm{X}^{*}$.

\section{Intervenção I - Instruções teóricas}

Antes do início da coleta de dados, os terapeutas foram instruídos a ler dois textos, que lhes foram enviados por e-mail: "Técnica terapêutica: as cinco regras" (capítulo 4 de Tsai, M., Kohlenberg, R., J., Kanter, J. W., Kohlenberg, B., Follette, W. C., \& Callaghan, G. M., 2011) e “Aplicação clínica da psicoterapia analítica funcional” (capítulo 2 de Kohlenberg, R. J., \& Tsai, M., 2001). O objetivo era 
garantir que todos os participantes tivessem a mesma instrução e pudessem ter a compreensão da FAP, incluindo as cinco regras do terapeuta, os CCRs e o modelo da ACL. Além disso, os participantes receberam instruções para a elaboração da conceituação de caso, conforme modelo da FAP (Tsai et al., 2009, p.213). Os participantes foram orientados a desenvolvê-la de modo a contemplar uma breve história de vida e da rotina do cliente, descrevendo as principais queixas e dificuldades, referentes ao momento em que buscaram a terapia também referentes ao momento atual (caso houvesse diferença entre eles), bem como a descrição dos CCRs1 e 2, e os Os 1 e 2 atuais. Esta conceituação de caso tem como finalidade possibilitar a categorização das sessões com o instrumento FAPRS pela pesquisadora e pelos aferidores de concordância. Os participantes foram instruídos a contatar a pesquisadora caso houvesse algo a ser alterado ao longo da coleta.

\section{Etapa I - Coleta Pré-treino}

Início da coleta de dados, na qual as sessões dos participantes começaram a ser gravadas.

T1 e sua cliente tiveram cinco sessões coletadas, transcritas e categorizadas. T2 teve nove sessões gravadas, das quais cinco foram sorteadas para serem transcritas e categorizadas. Desta forma, ambos os participantes tiveram cinco sessões de coleta de dados nesta fase.

Após a realização da coleta das cinco ses sões de linha de base, foi introduzida a variável independente - o workshop. 


\section{Intervenção II - Workshop}

O workshop teve 23 participantes no total, incluindo os dois participantes desta pesquisa. Todos os participantes do workshop receberam um e-mail contendo quatro textos, sendo dois deles os mesmos enviados aos participantes do estudo, além de:

1) Tsai, M., Callaghan, G. M. \& Kohlenberg, R. J. (2013). The use of awareness, courage, therapeutic love, and behavioral interpretation in functional analytic psychotherapy. Psychotherapy, 50(3), 366-370.

2) Weeks, C. E., Kanter, J. W., Bonow, J. T., Landes, S. J. \& Busch, A. M. (2012). Translating the theoretical into practical: a logical framework of functional analytic psychotherapy interactions for research, training and clinical purposes. Behavior modification, 36(1), 87-119.

A leitura dos textos teve como objetivo garantir que os participantes adquirissem conhecimentos básicos sobre a FAP, tornando-se aptos a acompanhar e compreender os conteúdos abordados. Todos os 23 participantes foram orientados a realizar tarefas que seriam retomadas no workshop. Uma dessas tarefas consistia na elaboração de um pequeno resumo sobre eventos importantes na vida do participante e na identificação dos próprios CCRs1 e 2. A outra tarefa consistia no "exercício para se libertar da vergonha" que é realizado durante o workshop, mas que pode requerer algum preparo prévio (caso o participante queira levar algum material para apresentar aos demais).

Em seguida, os terapeutas participaram do workshop para treinamento de habilidades terapêuticas necessárias para a condução da FAP, conforme modelo desenvolvido por Jonathan Kanter, e traduzido e ministrado no Brasil por Alessandra Villas-Bôas. Seu início se deu após o preenchimento da escala FAPIS por todos os 
participantes presentes. O treino teve duração de dois dias, cada um deles compreendendo uma jornada de oito horas.

O workshop seguiu uma sequência similar a uma sessão FAP, buscando aplicar e ao mesmo tempo ensinar a prática das cinco regras. O começo consistiu na parte teórica, em que se enfatizou a importância dos relacionamentos interpessoais e sua relação com o sofrimento, não só dos clientes, mas também dos terapeutas em suas relações pessoais. Houve a explicação dos conceitos básicos da FAP, com exemplos de conceituações de caso, e ainda explicações sobre a razão de se utilizar exercícios experienciais nas etapas seguintes do curso.

Em seguida, da mesma forma que ocorre em uma sessão de terapia, estabeleceu-se um contrato verbal em torno da importância de se manter o sigilo de tudo o que fosse exposto durante os exercícios ali realizados, garantindo, assim, a preservação da ética.

Ao final da parte teórica, iniciaram-se os exercícios experienciais. Para isso, ocorreu a organização da turma, distribuída ora em duplas e ora em pequenos grupos compostos por duas duplas. A composição das duplas foi obtida a partir da escolha dos participantes, de forma que se sentissem confortáveis e seguros uns com os outros. Nesse momento, houve uma divisão de papéis que se alternavam ao longo do workshop. Um participante (da dupla ou do grupo) assumia o papel de cliente enquanto o (s) outro (s) assumia (m) o papel de terapeuta.

O primeiro exercício era individual e tratava-se de escrita livre, no qual os participantes identificavam seus comportamentos problema (1) e suas dificuldades no dia a dia, em sessão e, potencialmente, no workshop. 
Em seguida, no grupo de quatro participantes, cada um compartilhou com os demais suas dificuldades e seus principais objetivos de melhora para que todos estivessem atentos às suas possíveis ocorrências destes (Regra 1).

Os exercícios tinham por objetivo de evocar nos participantes-clientes os comportamentos de melhora (indicados no exercício anterior), para os quais os participantes-terapeutas foram orientados a prover consequências potencialmente reforçadoras (Regra 3). Em seguida, o participante-cliente, que recebeu a consequenciação deveria explicitar para os demais, qual aspecto da consequenciação dada pareceu contribuir para aumentar a possibilidade de ocorrência de sua resposta. Desse modo, dois repertórios estavam sendo treinados ao mesmo tempo: o de melhora no participante-cliente, aumentando em paralelo seu autoconhecimento (discriminação das variáveis que controlam seu comportamento), e o de dar consequenciação reforçadora (Regra 3) no repertório do outro, enquanto participanteterapeuta. Progressivamente, busca-se com os exercícios aprimorar tanto a identificação dos comportamentos problema e de melhora (Regra 1) como a forma de consequenciar o comportamento dos demais (Regra 3), treinando habilidades como empatia e precisão na identificação dos CCRs (nessa turma essas foram as habilidades treinadas, mas outras poderiam ter sido escolhidas a depender da demanda dos participantes). Para isso, são primeiramente discutidas estratégias teóricas para obter melhores consequenciações e, em seguida, essas estratégias são colocadas em prática.

Apresenta-se, seguir, um exemplo de como o primeiro exercício se desenvolve nos workshops: O participante-cliente é incentivado a contar ao seu parceiro de dupla um recorte de sua história de vida de forma que a emissão dessa resposta seja um comportamento de melhora. O participante-cliente engaja-se, então, na resposta, 
vivenciando e expressando emoções e respostas vulneráveis à punição interpessoal. O participante-terapeuta que ouve o relato do colega é orientado a responder de forma genuína, promovendo segurança e aceitação ao colega, ou seja, provendo consequências potencialmente reforçadoras, e não punitivas. Por fim, o participantecliente que contou parte de sua história descreve ao colega o efeito que essa consequenciação teve sobre a emissão de seu comportamento de melhora. $\mathrm{Na}$ sequência, os papéis são invertidos e o participante-terapeuta que proveu consequência assume o papel de participante-cliente, contando um recorte de sua história e recebendo a consequenciação do colega.

Após a realização de uma série de exercícios com esse formato, os participantes foram convidados a refletir sobre seus objetivos de vida e a discutir com seu par o quanto o desenvolvimento ocorrido ao longo do workshop seguiu essa direção, de forma semelhante ao que ocorre em uma sessão FAP quando CCR3 e Regra 5 são emitidos.

É importante ressaltar que a condução do workshop requer preparo por parte do ministrante. Ao longo da condução do mesmo, muitos imprevistos podem acontecer, como algum participante ficar mobilizado e fragilizado demais, agindo de forma não produtiva. Portanto, é de extrema importância que o condutor do workshop saiba identificar e lidar com eventuais imprevistos e que seja capaz de tomar decisões funcionalmente (podendo, inclusive, propor mudanças na realização dos exercícios para a sequência do workshop), adequando-se, assim, às demandas geradas e garantindo a continuidade do desenvolvimento e a segurança emocional dos participantes. Desse modo, a elaboração de um roteiro de como o workshop foi conduzido poderia erroneamente levar a crer que a mera ação de segui-lo poderia garantir o objetivo e a segurança da condução. Na realidade, porém o preparo do 
mesmo exige muitos conhecimentos teóricos e práticos específicos, que vão muito além de um roteiro.

\section{Etapa II - Coleta Pós-treino}

Nessa etapa, os dois terapeutas da pesquisa deram continuidade à psicoterapia, conduzindo as sessões sem nenhuma instrução especificada pela pesquisadora, e continuaram as gravações após o workshop até que fosse coletada a sessão de seguimento e, então, instruídos a cessar as gravações. As cinco sessões após a intervenção e a sessão de seguimento foram categorizadas, procurando-se verificar possíveis efeitos do workshop sobre os comportamentos de terapeuta e de cliente, ou seja, mudanças na frequência das categorias de ambos.

\section{Etapa III - Coleta de seguimento}

A terceira etapa consistiu em gravar uma sessão de acompanhamento de cada participante, três meses após a realização do workshop sem que houvesse qualquer instrução para o terapeuta. Este procedimento visa observar se os resultados de possíveis mudanças após o workshop se mantêm com a passagem do tempo.

\section{Etapa IV - Processo de categorização e análise dos dados}

Todas as sessões cujos dados foram analisados nessa pesquisa foram transcritas integralmente, e todas as ocorrências verbais foram analisadas e categorizadas pela pesquisadora de acordo com as categorias definidas no manual do FAPRS (Callaghan \& Follette, 2008, adaptado). Cada unidade de análise, nesse caso, é definida por uma fala emitida por terapeuta ou cliente, delimitada pela fala seguinte emitida pela outra pessoa da díade. 
Após a categorização das sessões, calculou-se a ocorrência de cada categoria em porcentagem de frequência relativa, obtida pelo quociente entre a frequência absoluta de cada unidade de análise (categoria definida pelo instrumento) e o número total de ocorrências em cada sessão. A utilização dos dados em frequência relativa os torna comparáveis entre sessões, em razão da variação considerável no número total de falas em cada sessão.

\section{Etapa V - Aferição de concordância entre observadores}

Para a aferição de concordância entre observadores, foram selecionadas duas psicólogas, sendo cada uma delas responsável por uma díade terapeuta-cliente diferente. Foram sorteadas 3 sessões de cada díade para que o número de sessões avaliadas correspondesse a pelo menos $20 \%$ do total. Essas sessões foram enviadas juntamente com sua conceituação de caso correspondente para cada aferidora para que fossem analisadas. As sessões enviadas não tinham identificação quanto à fase a qual pertenciam, de modo a evitar possíveis vieses. Ambas assinaram o Termo de Responsabilidade (Anexo 4) para que fosse garantido o sigilo. As aferidoras selecionadas estão descritas a seguir:

Aferidora 1: A Aferidora 1 é também a Treinadora dessa pesquisa. Foi selecionada por ter vasta experiência com FAP e com o instrumento utilizado para categorização, não sendo necessário um treino específico para manejo do instrumento. A Aferidora 1 realizou a aferição de concordância da Díade 1 (P1 e C1). As sessões aferidas por ela tiveram concordâncias de 85\% (Kappa=0,76); 80\% $(\mathrm{Kappa}=0,72)$ e $90 \%(\mathrm{Kappa}=0,82)$, portanto, a média de concordância em porcentagem foi de $85 \%$ e índice Kappa acima do mínimo aceitável para todas as sessões. 
Aferidora 2: A Aferidora 2 é psicóloga há sete anos e faz mestrado em Psicologia Clínica. Ela foi selecionada por utilizar o mesmo instrumento de categorização em sua pesquisa e por ter conhecimento sólido em FAP. A Aferidora 2 realizou a aferição de concordância da Díade 2 (P2 e C2). Os níveis de concordância observados entre as categorizações realizadas pela pesquisadora e pela Aferidora 2 foram de $78 \%(\mathrm{Kappa}=0,65) ; 80,1 \%(\mathrm{Kappa}=0,69)$ e $80,5 \%(\mathrm{Kappa}=0,68)$. A média de concordância em porcentagem foi de 79,5\%, ligeiramente abaixo do mínimo ideal (de 80\%), porém as três sessões atingiram índices Kappa satisfatórios (acima de 0,6).

As categorizações realizadas pelas a feridoras foram utilizadas para cálculo de concordância entre observadores, conforme definido por Kratochwill et al. (2012).

Para a aferição de concordância, compararam-se as categorizações realizadas pela pesquisadora com as realizadas pelas aferidoras. O cálculo de concordância foi realizado de duas formas: Primeiramente, somou-se a quantidade de categorias concordantes e calculou-se a porcentagem de categorias concordantes em cada sessão. A outra forma de cálculo foi obtida utilizando-se o índice Kappa (Cohen, 1960), melhor descrito na seção Análise dos dados.

\section{Análise dos dados}

Inicialmente, foram categorizados de acordo com as categorias do FAPRS (Callaghan \& Follette, 2008, adaptado) os comportamentos dos terapeutas e seus respectivos clientes. De cada díade terapeuta-cliente, foram sorteadas três sessões para serem categorizadas por um avaliador independente com conhecimento e experiência com o instrumento FAPRS e com a FAP, com o objetivo de avaliar a concordância entre observadores quanto à categorização - considerando que os 
valores aceitáveis de concordância são, segundo Hartmann, Barrios e Wood (2004), de 80 a 90 se medidos por porcentagem, ou de ao menos 0.60 , se medidos pelo Kappa (Cohen, 1960).

A utilização do índice Kappa (Cohen, 1960) se justifica por este ser um índice de concordância que desconta concordâncias casuais esperadas, e por permitir analisar dados com dois ou mais fatores (no caso, as categorias de terapeuta e de cliente do instrumento FAPRS, Callaghan \& Follette, 2008, adaptado), envolvendo dois ou mais observadores (neste estudo, a pesquisadora e a aferidora de concordância). Um índice positivo indica que os observadores concordam com maior frequência do que seria esperado pelo acaso. Índices entre 0.61 a 0.80 são considerados como concordância substancial, e entre 0.81 e 0.99 são considerados como concordância quase perfeita. Ressalta-se que esse é o índice menos controverso e com mais ampla aplicação a diferentes tipos de dados a diferentes números de observadores. Sendo assim, o Kappa é recomendado como índice de concordância para pesquisas de observação comportamental (Suen \& Ary, 1989).

Verificou-se se houve mudanças na distribuição e frequência das categorias dos comportamentos dos terapeutas e dos clientes nas etapas I e II e no seguimento não apenas pelo decorrer da terapia, mas em função do workshop. A análise dos dados permite verificar se, após a exposição ao treino, os terapeutas modificaram a forma de conduzir os atendimentos, passando a emitir com maior frequência as categorias Regra 1, Regra 2, TRB1, TRB2, Regra 4, Regra 5, TO1, TO2 e com menor frequência a categoria FCCR em relação ao que emitiam antes da intervenção, o que indicaria maior aderência à terapia FAP por parte do terapeuta. Além disso, observou-se a ocorrência de mudanças na emissão das categorias referentes à melhora do cliente nas sessões após intervenção: CCR1, CCR2, O1 e O2 (Callaghan 
\& Follette, 2008, adaptado) em relação às sessões realizadas antes da intervenção, o que indicaria melhora do cliente após a intervenção para o terapeuta.

\section{Aspectos Éticos}

Em consonância com a Resolução 466/12, do Conselho Nacional de Saúde do Ministério de Saúde, os preceitos éticos foram atendidos na medida em que os participantes e a instituição foram informados sobre os objetivos e procedimentos da pesquisa e por terem sido respeitados os possíveis participantes como pessoas autônomas e livres para decidir sobre sua participação. O presente estudo foi submetido para apreciação pela Plataforma Brasil e aprovado em 22/08/2014 sob o número CAAE 33656014.3.0000.5561.

Todos os participantes terapeutas e clientes assinaram termo de consentimento livre e esclarecido (Anexos 2 e 3, respectivamente) e os transcritores, a pesquisadora e aferidores de concordância assinaram o termo de responsabilidade (Anexo 4) a fim de garantir o sigilo. Todos os termos foram redigidos em duas vias, sendo uma para a pesquisadora e outra para o participante ou colaborador. Quaisquer dados de identificação ou detalhes que permitissem a identificação dos envolvidos foram modificados.

\section{Resultados}

Inicialmente, sete terapeutas tiveram interesse na pesquisa e preencheram os critérios para participar. Entretanto, quatro deles não puderam concluir sua participação devido a faltas e/ou desistência de clientes, o que ocorreu antes da intervenção II (workshop). Em outro caso, a díade teve seus dados coletados, mas não 
aproveitados em função da má qualidade da gravação. Portanto, dois terapeutas participaram da coleta e intervenção e tiveram seus dados analisados nesse estudo.

Os dados a seguir apresentados são de 22 sessões analisadas e categorizadas no total, correspondendo a 11 para cada cliente. Foram analisadas 6.176 (seis mil, cento e setenta e seis) unidades de análise (falas) no total conforme apresentado na Tabela 3.

Tabela 3

Unidades verbais em cada Etapa para cada díade participante

\begin{tabular}{ccccc}
\hline $\begin{array}{c}\text { Etapas/ } \\
\text { Díades }\end{array}$ & Etapa I & Etapa II & Etapa III & TOTAL \\
\hline $\mathbf{1}$ & 276 & 376 & 98 & 750 \\
$\mathbf{2}$ & 2748 & 2208 & 470 & 5426 \\
\cline { 3 - 4 } & & & TOTAL & 6176 \\
\hline
\end{tabular}

Nota-se que a quantidade de unidades verbais difere consideravelmente entre as díades, embora a quantidade de sessões seja a mesma. Isso resultou das diferentes características dos clientes e dos terapeutas, especialmente pelo fato de que, na Díade 1, C1 fazia longas falas sem que houvesse qualquer interrupção por T1, de forma a produzir poucas unidades verbais por sessão, enquanto o C2 fazia falas curtas, o que provavelmente demandava de T2 que fizesse mais perguntas. Considerando essa diferença, optou-se pela análise da frequência relativa (porcentagem), pois dessa forma, os dados tornam-se comparáveis, o que não seria viável utilizando-se de números brutos.

\section{Dados do FAPRS}

Os dados resultantes da análise dessas unidades verbais de acordo com o instrumento FAPRS estão apresentadas na Tabela 4. 
Tabela 4

Porcentagens arredondadas de ocorrência de categorias do FAPRS de terapeuta e cliente por sessão

\begin{tabular}{|c|c|c|c|c|c|c|c|c|c|c|c|c|c|c|c|}
\hline $\begin{array}{c}\text { Sessões/ } \\
\text { Categorias }\end{array}$ & S1 & S 2 & S 3 & S 4 & S 5 & S 6 & S 7 & S 8 & S 9 & S10 & S 11 & S 12 & S13 & S14 & Seguimento \\
\hline CPR C1 & & 27 & 20 & 28 & 27 & 34 & 32 & 21 & 32 & & 35 & 27 & & & 35 \\
\hline CPR C2 & & 46 & 46 & 44 & & 44 & & 45 & & 39 & 44 & 42 & 36 & 39 & 41 \\
\hline CCR1 C1 & & 0 & 11 & 0 & 0 & 0 & 6 & 11 & 5 & & 0 & 5 & & & 1 \\
\hline CCR1 C2 & & 1 & 1 & 1 & & 0 & & 2 & & 1 & 0 & 2 & 2 & 1 & 1 \\
\hline CCR2 C1 & & 12 & 16 & 14 & 10 & 11 & 13 & 15 & 7 & & 6 & 13 & & & 9 \\
\hline CCR2 C2 & & 1 & 3 & 3 & & 5 & & 3 & & 7 & 5 & 4 & 9 & 6 & 8 \\
\hline $01 \mathrm{C} 1$ & & 0 & 0 & 2 & 0 & 1 & 0 & 0 & 1 & & 0 & 5 & & & 0 \\
\hline $01 \mathrm{C} 2$ & & 0 & 0 & 0 & & 0 & & 0 & & 0 & 0 & 0 & 0 & 0 & 0 \\
\hline O2 C1 & & 12 & 3 & 8 & 14 & 3 & 0 & 0 & 5 & & 10 & 2 & & & 4 \\
\hline $\mathrm{O} 2 \mathrm{C} 2$ & & 1 & 1 & 2 & & 1 & & 0 & & 3 & 1 & 2 & 3 & 4 & 0 \\
\hline Regra 1 T1 & & 0 & 1 & 0 & 2 & 1 & 0 & 0 & 0 & & 0 & 0 & & & 0 \\
\hline $\operatorname{Regra} 2 \mathrm{~T} 2$ & & 0 & 0 & 0 & & 0 & & 0 & & 1 & 0 & 0 & 1 & 1 & 0 \\
\hline Regra $2 \mathrm{~T} 1$ & & 0 & 3 & 0 & 4 & 1 & 4 & 0 & 4 & & 0 & 1 & & & 3 \\
\hline $\operatorname{Regra} 2 \mathrm{~T} 2$ & & 2 & 2 & 1 & & 4 & & 3 & & 3 & 1 & 2 & 3 & 3 & 6 \\
\hline Regra 5 T1 & & 3 & 0 & 0 & 0 & 0 & 3 & 0 & 0 & & 1 & 0 & & & 0 \\
\hline Regra 5 T2 & & 0 & 0 & 0 & & 0 & & 0 & & 0 & 0 & 0 & 0 & 0 & 0 \\
\hline TPR T1 & & 33 & 30 & 40 & 35 & 36 & 31 & 19 & 36 & & 46 & 36 & & & 39 \\
\hline TPR T2 & & 47 & 45 & 48 & & 45 & & 45 & & 41 & 46 & 43 & 42 & 44 & 38 \\
\hline TRB1 T1 & & 0 & 11 & 0 & 0 & 0 & 0 & 17 & 6 & & 0 & 6 & & & 2 \\
\hline TRB1 T2 & & 0 & 0 & 0 & & 0 & & 2 & & 1 & 0 & 2 & 1 & 0 & 1 \\
\hline TRB2 T1 & & 12 & 5 & 8 & 8 & 11 & 13 & 17 & 4 & & 1 & 6 & & & 7 \\
\hline TRB2 T2 & & 1 & 1 & 1 & & 1 & & 1 & & 4 & 2 & 2 & 2 & 1 & 4 \\
\hline
\end{tabular}

As porcentagens de ocorrências de cada categoria por sessão estão apresentadas na Tabela 4. As sessões da Etapa II (Pós-treino) estão indicadas em itálico, e têm início na Sessão 7 para a Díade 1 e na sessão 10 para a Díade 2. É possível notar que a distribuição 
entre as categorias difere entre as díades, como exemplo, as categorias CCR1 e CCR2 aparecem em porcentagem de ocorrência consideravelmente maiores para $\mathrm{C} 1$ que para $\mathrm{C} 2$. Consequentemente, as categorias TRB1 e TRB2 seguem a mesma tendência. Além disso, algumas categorias tiveram poucas ou nenhuma ocorrência em muitas sessões, como O1, Regra 1, Regra 5, TRB1 e TTR.

Comparações feitas entre fases com base na média obtida para cada etapa e para cada participante estão ilustradas a seguir. As categorias selecionadas para serem ilustradas são aquelas relevantes à FAP e que tiveram ocorrência suficiente para que fosse possível a visualização dos dados nos gráficos. Assim, dentre elas não estão as categorias CPR e TPR, por não estarem relacionadas ao protocolo, e as categorias CCR3, Regra 1, Regra 5 e TTR, pois, embora sejam componentes importantes na FAP, não tiveram ocorrências suficientes para serem ilustradas em gráficos - portanto, constam apenas na Tabela 4. Quanto às categorias TPR e CPR, elas ocorrem com maior frequência em todas as sessões comparativamente às outras categorias, uma vez que envolvem todas as verbalizações que não se encaixam nas outras categorias.

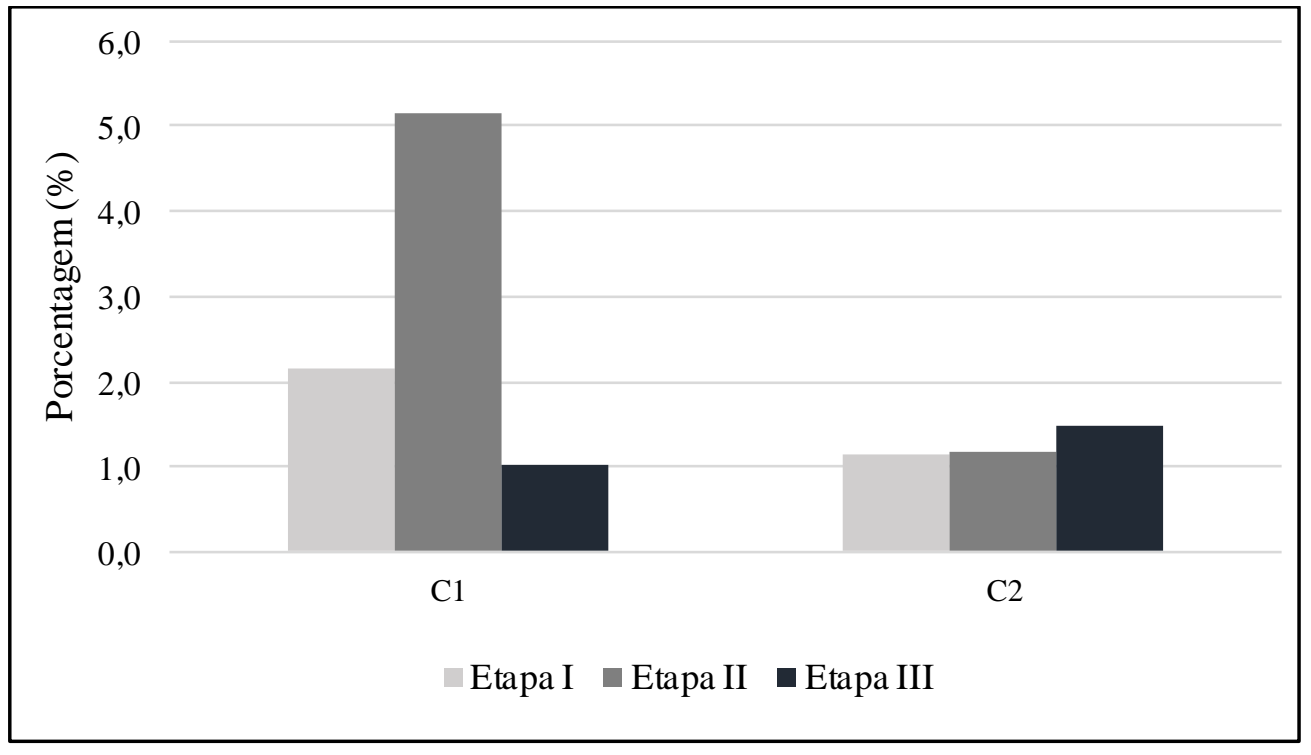

Figura 4. Média dos CCRs1 em cada etapa para cada cliente 
Observa-se na Figura 4 que a média de CCRs1 é maior para C1 do que para C2 na Etapa I, diferença que se acentua na Etapa II, em que C1 emite quase o dobro de CCRs1 após o workshop. Na Etapa de seguimento, a quantidade de CCRs1 diminui consideravelmente para $\mathrm{C} 1$ e tem um ligeiro aumento para $\mathrm{C} 2$. Na FAP, normalmente espera-se que a emissão de CCRs1 diminua ao longo da terapia, o que não ocorre para ambas as díades. A Díade 2 apresenta um aumento apenas discreto na Etapa III. É importante destacar que a presença de CCRs1 de C1 na Etapa I se deve apenas a uma sessão, a segunda da coleta de dados: nas outras quatro não houve emissões de CCRs1, conforme pode-se observar na Figura 11 e na Tabela 4.

As médias de ocorrência de CCRs2 em cada etapa para ambas as díades são demonstradas na Figura 5. Nela, é possível observar que, ao longo do procedimento, a ocorrência de CCRs2 foi diminuindo para $\mathrm{C}$ 1, enquanto para $\mathrm{C} 2$ observa-se a tendência oposta, aumentando a ocorrência de CCRs2 da Etapa I para a Etapa II e também da Etapa II para a Etapa III.

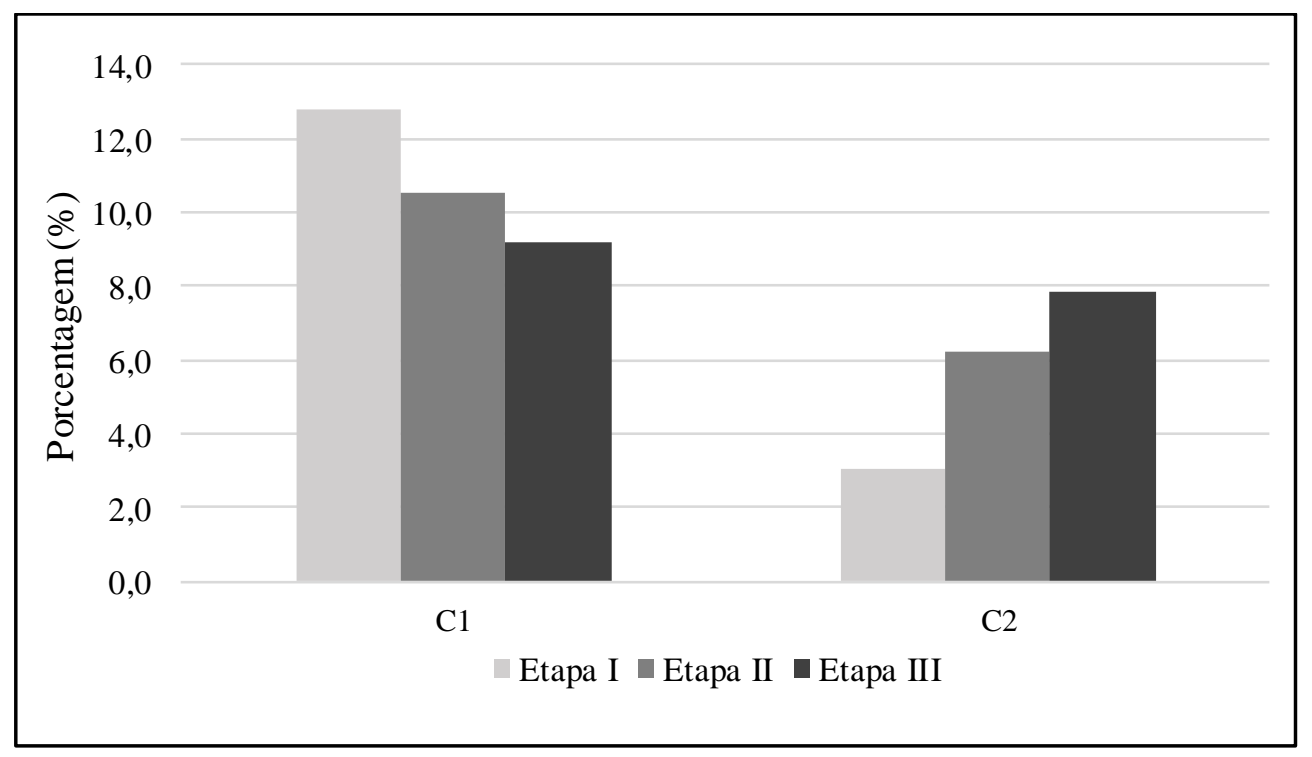

Figura 5. Média porcentual dos CCRs2 em cada etapa para cada cliente 
Essa tendência decrescente observada para a Díade 1 se opõe ao esperado, apesar de os CCRs2 terem acontecido em maior frequência do que os CCRs1. Já para a Díade 2, é possível notar que a emissão de CCRs2 aumentou consideravelmente ao longo da coleta, confirmando o que se previa.

Para verificar o impacto do workshop no comportamento dos terapeutas, a seguir, serão apresentados gráficos que ilustram as médias obtidas em cada etapa de algumas categorias do terapeuta.

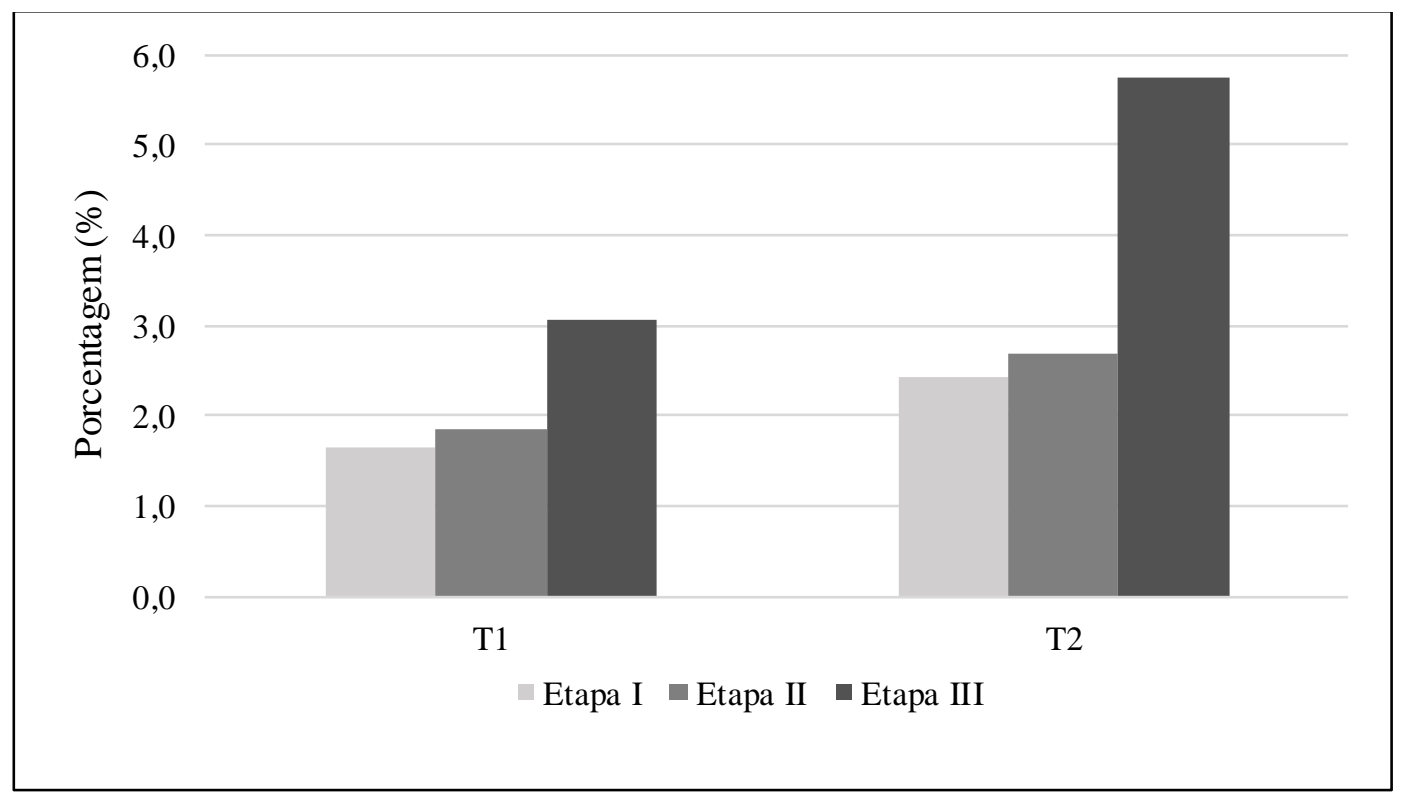

Figura 6. Média porcentual de Regra 2 em cada etapa para cada terapeuta

A Figura 6 ilustra a média obtida das porcentagens de ocorrências de evocação dos CCRs pelos terapeutas em cada etapa. Para ambos os terapeutas, T1 e T2, houve apenas um aumento discreto da Etapa I para a Etapa II, com um aumento maior na Etapa III, principalmente para T2. Seria esperado aumento maior de Regras 2 após o workshop. Entretanto, observa-se um aumento importante na Etapa III, o que pode indicar que o repertório do terapeuta de evocar CCRs foi fortalecido ao longo do tempo, embora de forma não significativa nas cinco semanas seguintes ao workshop. 


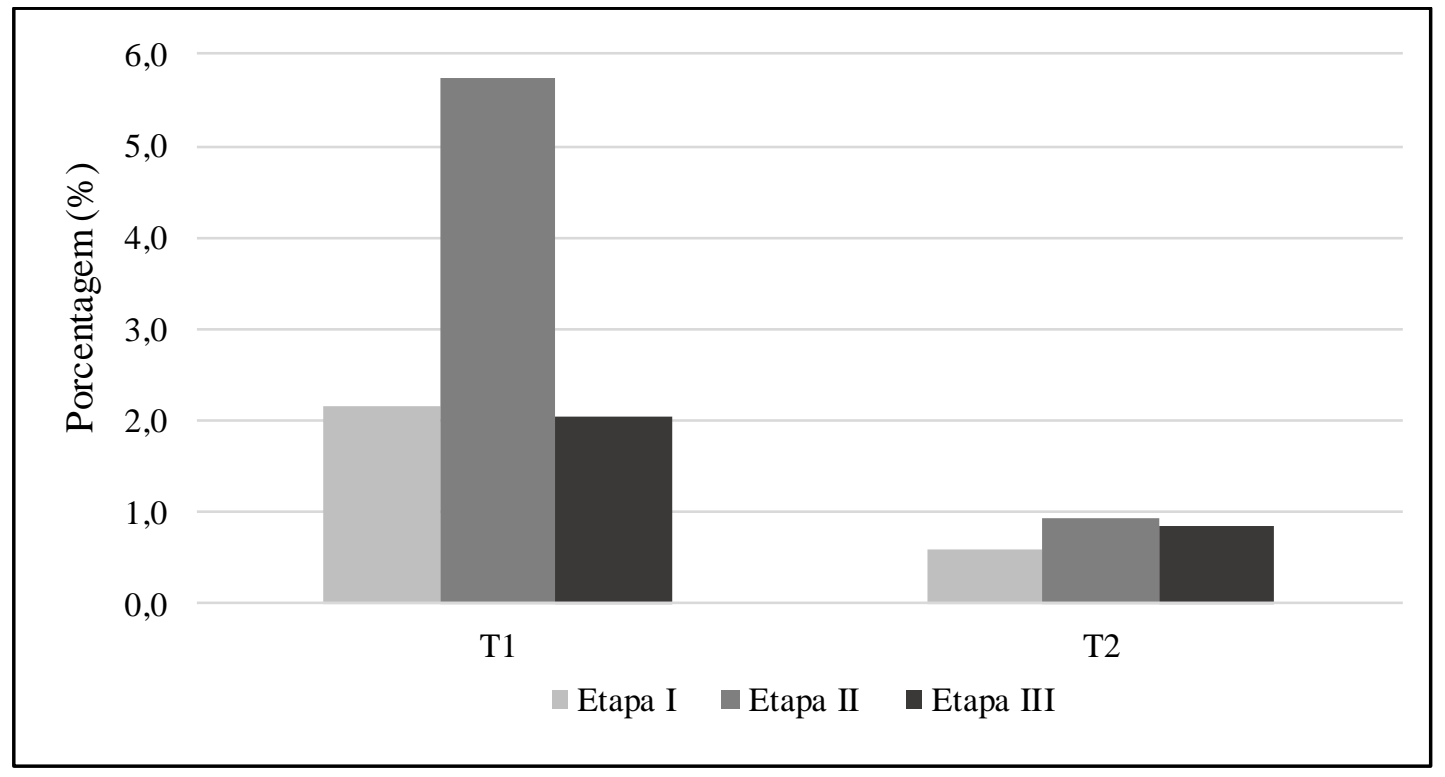

Figura 7. Média de TRB1 em cada etapa para cada terapeuta

Na Figura 7 é possível observar as médias obtidas das ocorrências da categoria TRB1. Assim como as ocorrências de CCRs1 para C1, a ocorrência de TRBs1 tem aumento considerável na Etapa II para T2, o que é esperado, já que demonstra habilidade da terapeuta de consequenciar esses CCRs, e diminui na Etapa III. A análise desses dados será apresentada na seção Discussão. Já para T2, a ocorrência de TRBs1 é baixa nas três etapas do procedimento, com aumento discreto após o workshop. 


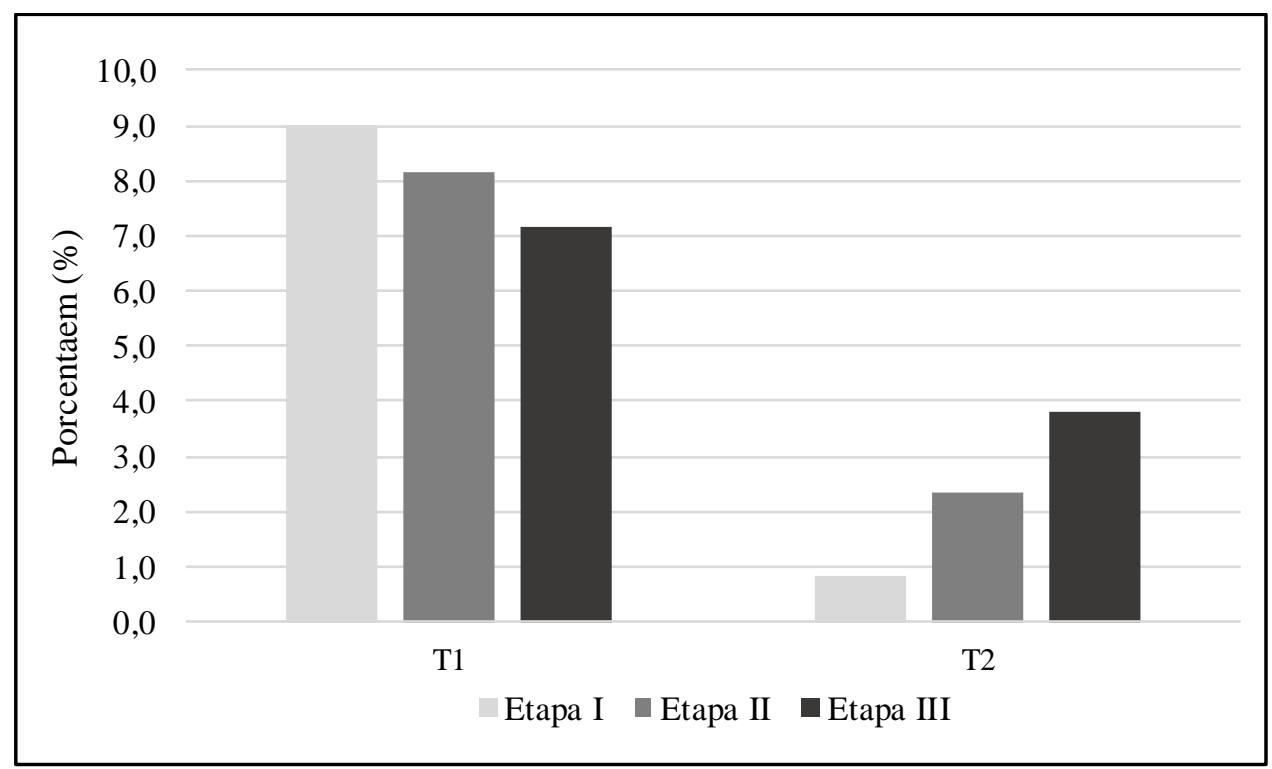

Figura 8. Média em porcentagem de TRB2 em cada etapa para cada terapeuta

A Figura 8 mostra as médias de ocorrência de TRB2 em cada Etapa, e nela é possível notar diminuição da consequenciação de CCR2 (ainda que não seja considerável) para T1 ao longo da coleta de dados. Assim como o observado com relação aos CCRs2, o efeito oposto é observado para T2, em que ocorre aumento importante da ocorrência ao longo das etapas do procedimento. Espera-se que os TRBs acompanhem a emissão de CCRs, o que de fato ocorre para ambas as díades. 


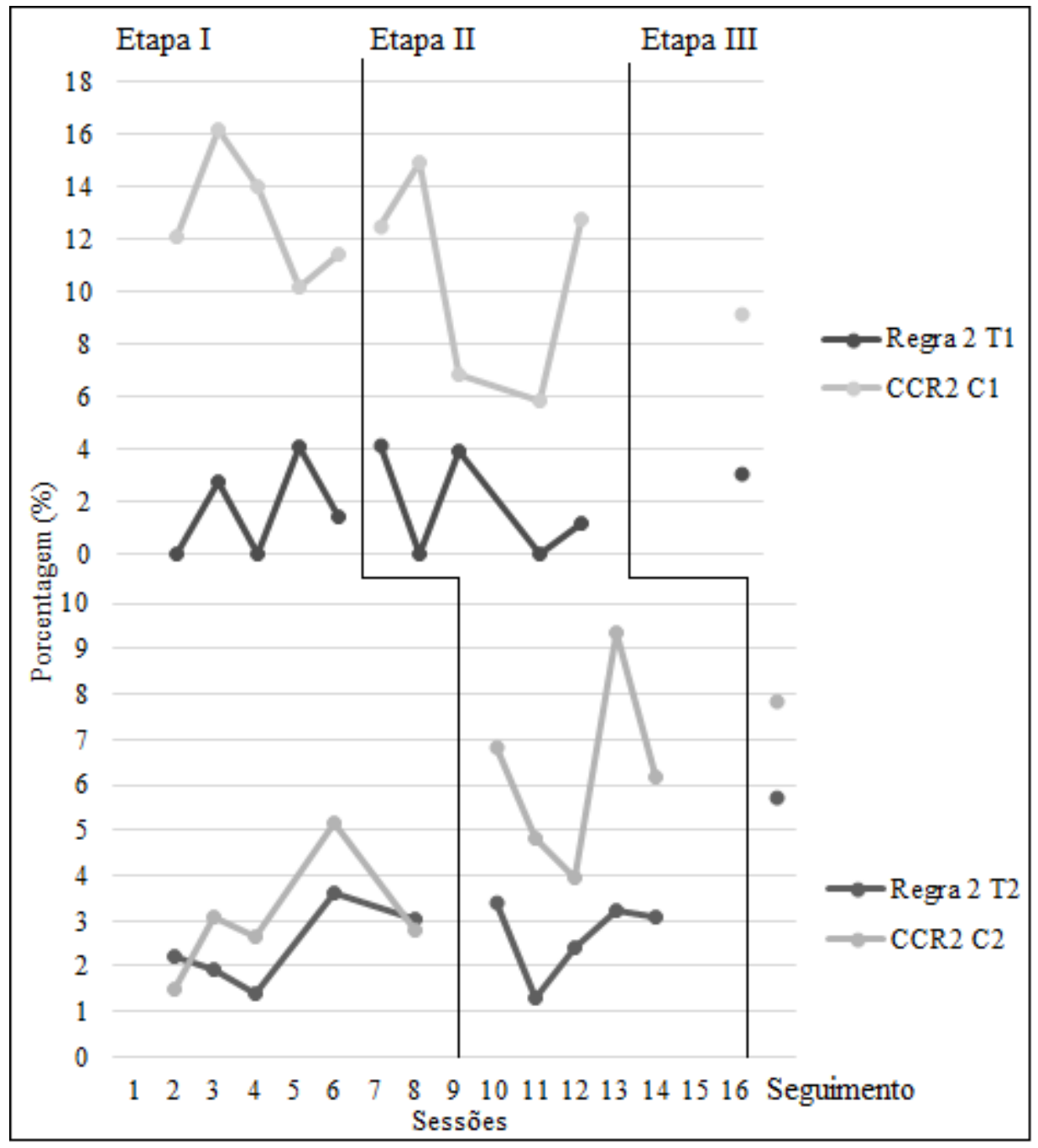

Figura 9. Porcentagem de Regras 2 e CCRs2 por sessão

A Figura 9 ilustra a porcentagem da ocorrência das categorias Regra 2 e CCR2 por sessão, para cada cliente e terapeuta. Para a Díade 1, as Regras 2 ocorrem de forma irregular tanto na Etapa I como na Etapa II, ou seja, não é possível identificar efeito das intervenções sobre o comportamento da T1 em evocar CCRs. Os CCRs2 da C1 também ocorrem com oscilações e sem uma tendência clara entre etapas, embora com alguma tendência decrescente e em porcentagem consideravelmente maior que as Regras 2.

Com relação à Díade 2, é possível notar que a emissão de Regras 2 não teve aumento considerável após a Intervenção II, bem como com a Díade 1, conforme seria esperado, com aumento na etapa de seguimento. Novamente, não se pode afirmar que as intervenções 
realizadas tiveram efeito sobre essa categoria. No entanto, a emissão de CCRs2 cresceu de forma importante na Etapa II e foi ainda mais alta na Etapa III, o que indica que a emissão de comportamentos de melhora de C2 seguiu na direção esperada ao longo do estudo.

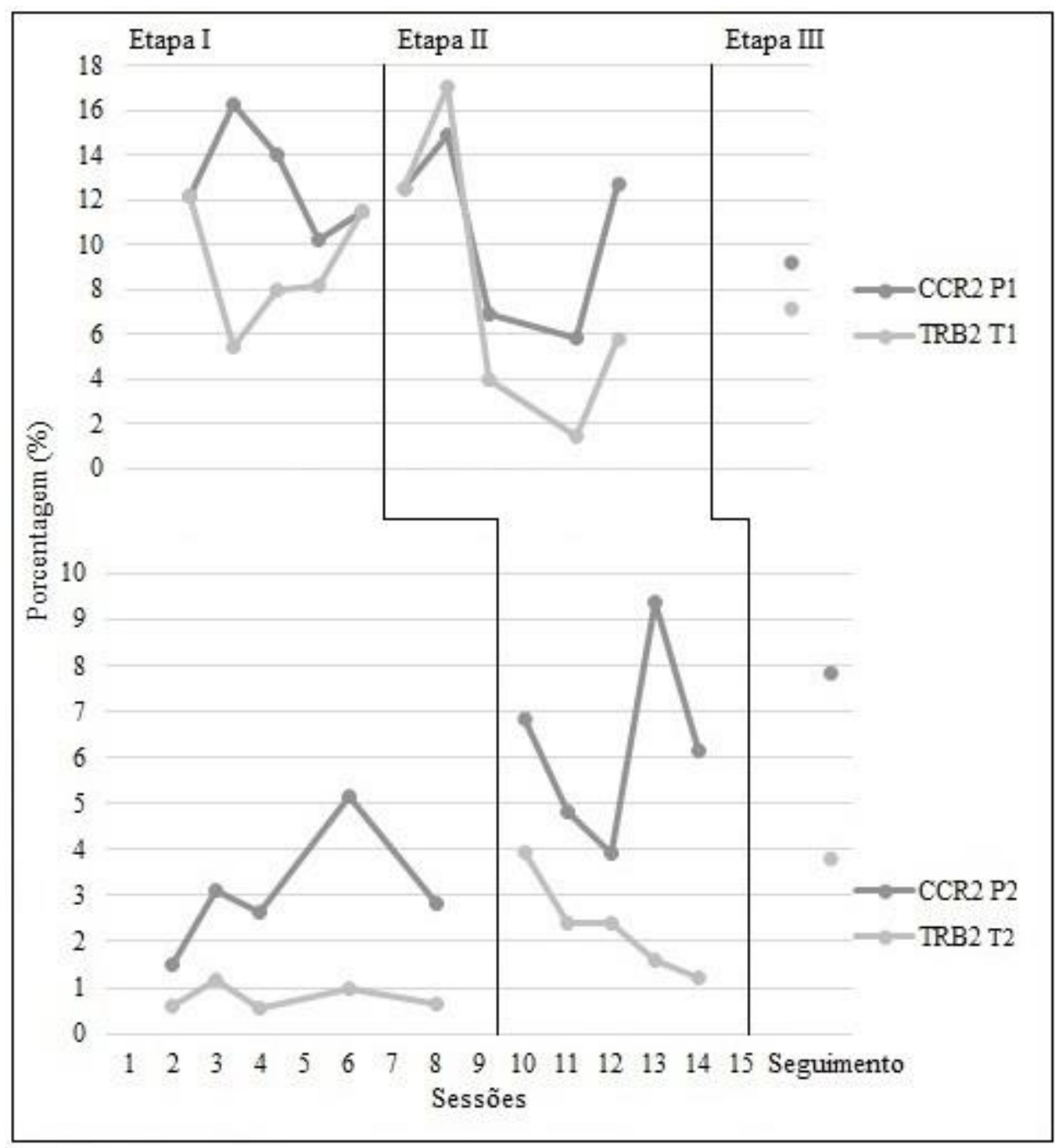

Figura 10. Porcentagem de CCRs2 e TRBs2 por sessão

A Figura 10 mostra as porcentagens de CCRs2 e das consequências providas pelos terapeutas, os TRB2. A Díade 1 apresenta linhas espelhadas no gráfico na Etapa I, ou seja, altas porcentagens de emissão de CCR2 e baixas de TRB2. Já na última sessão da Etapa I e na primeira sessão da Etapa II, as porcentagens estão próximas; e na segunda sessão após o workshop, as ocorrências de TRB2 superam as de CCR2. 
Com relação à segunda díade, há a tendência crescente de emissão de CCRs2 ao longo do procedimento, apesar de a porcentagem de TRB2 ter diminuído ao longo da Etapa II, o que pode ser observado pelo distanciamento entre as linhas na figura.

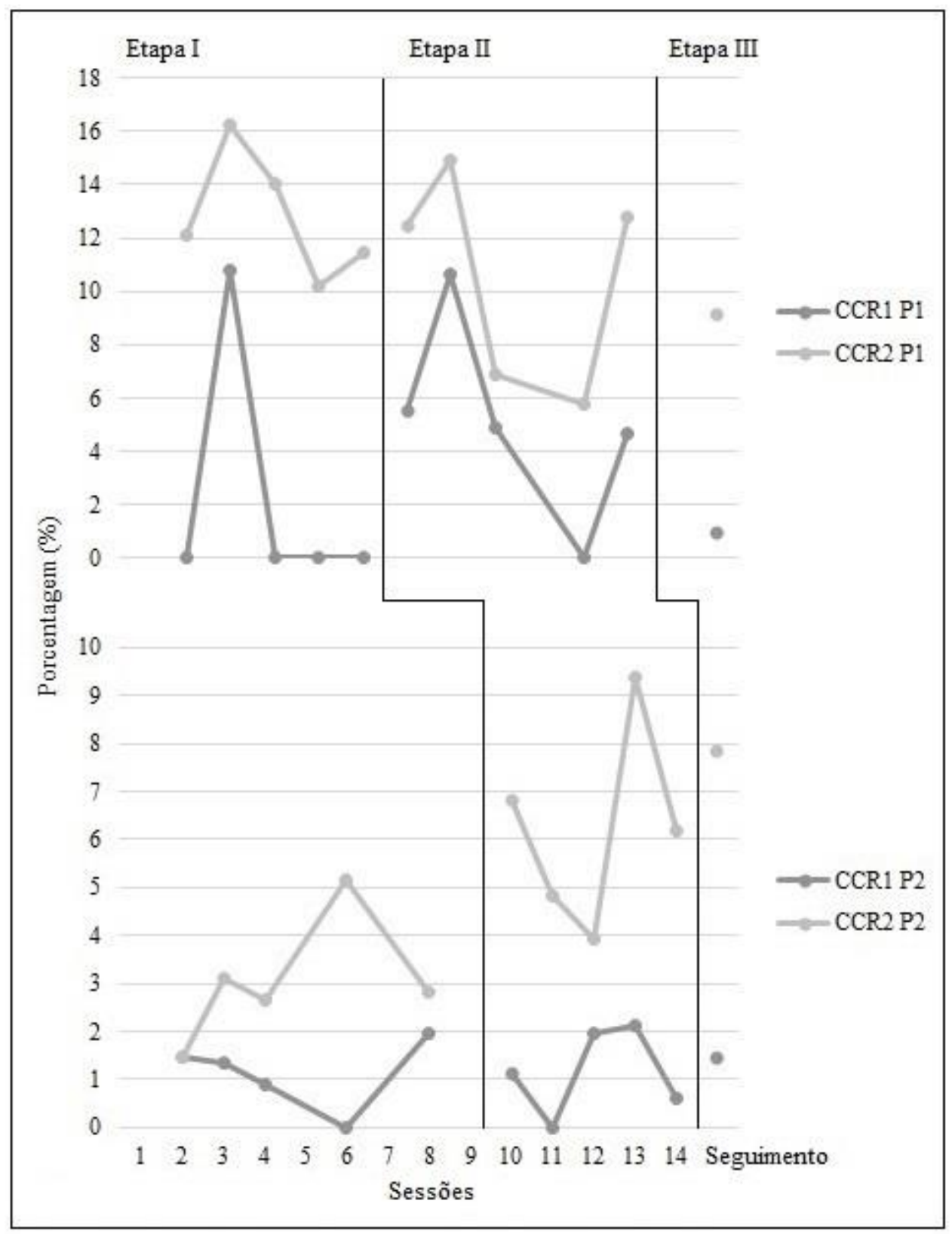

Figura 11. Porcentagens de CCRs1 e CCRs2 em todas as sessões da coleta

Na Figura 11 é possível observar a comparação entre as porcentagens de emissão de CCRs1 e de CCRs2 para cada cliente ao longo do procedimento. Para a primeira díade, é possível notar que as linhas de CCRs1 e 2 na Etapa I estão distantes (com exceção da sessão 
2), devido à alta ocorrência de CCrs2 e baixa ocorrência de CCRs1. Nas Etapas II e III, os CCRs2 mostram uma tendência decrescente, enquanto os CCRs1 passam a acontecer em maior frequência, porém, de forma irregular, não havendo nenhuma ocorrência na quarta sessão após a Intervenção II. Ao longo de toda a coleta, parece haver correlação positiva entre as emissões de CCR1 e CCR2 para essa díade.

Já para a Díade 2, é possível observar que as categorias CCRs1 e 2 têm uma diferença maior entre elas após o workshop, o que se mantém na coleta de seguimento. Assim, ao contrário do observado para a outra díade, os CCRs2 aumentaram após o treino do terapeuta, o que se alinha com o resultado esperado para essa pesquisa.

A Figura 12 ilustra a comparação entre as ocorrências de CCRs1 e TRBs1 em porcentagens. 


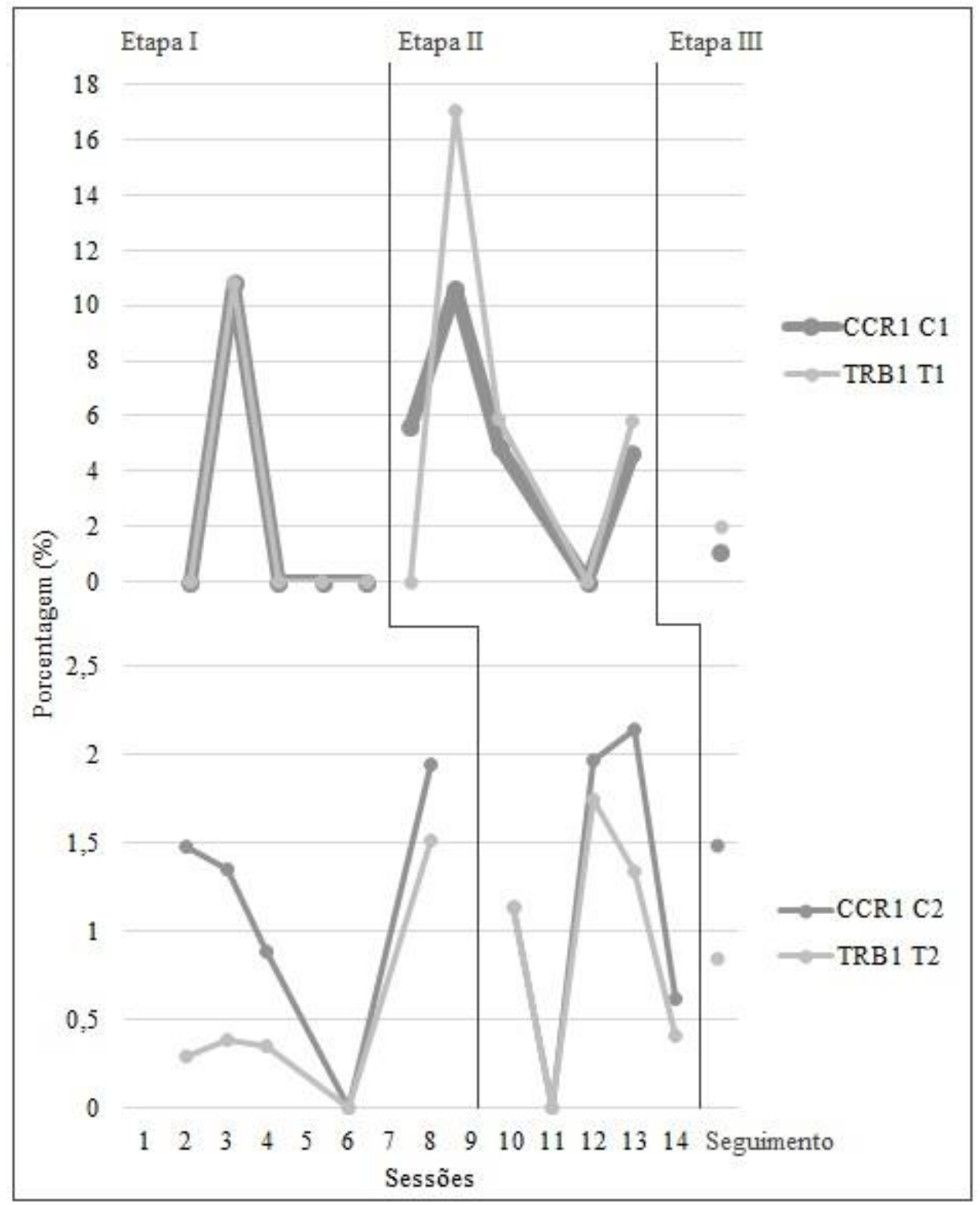

Figura 12. Porcentagens de CCRs1 e TRBS 1 em todas as sessões

Na Figura 12, estão ilustradas as ocorrências de CCRs1 e TRBs1. Espera-se que com o treino, a frequência de TRBs1 aumente, pois isso indicaria adesão ao protocolo FAP e maior eficácia do terapeuta em prover consequências aos CCRs1, seja punindo-os, bloqueando esquivas, seja evocando CCRs2 frente à emissão de CCRs1. Na Etapa I, ocorrem CCRs1 apenas na terceira sessão para $\mathrm{C} 1$, e $\mathrm{T} 1$ responde na mesma frequência. Já na primeira sessão da Etapa II, não há emissão de TRB1, embora tenha havido CCRs1. A partir da sessão seguinte, incluindo a coleta de seguimento, os TRBs1 se mantém acima da quantidade de 
CCRs1 (com exceção da sessão 11, em que não há ocorrência de CCR1, portanto, não poderia haver TRB1). As emissões de CCRs1 e, portanto, de TRBs1, são baixas na coleta de seguimento.

Para a Díade 2, não se observa tendência clara quanto às porcentagens de CCRs1, que ocorrem de maneira oscilante durante toda a coleta. No entanto, pode-se notar que nas três primeiras sessões de coleta, ocorrem consideravelmente menos TRBs1 em relação aos CCRs1, o que muda nas sessões seguintes, nas quais as porcentagens de CCRs1 e TRBs1 se mantém mais próximas, ainda que em nenhum momento essas linhas se cruzem.

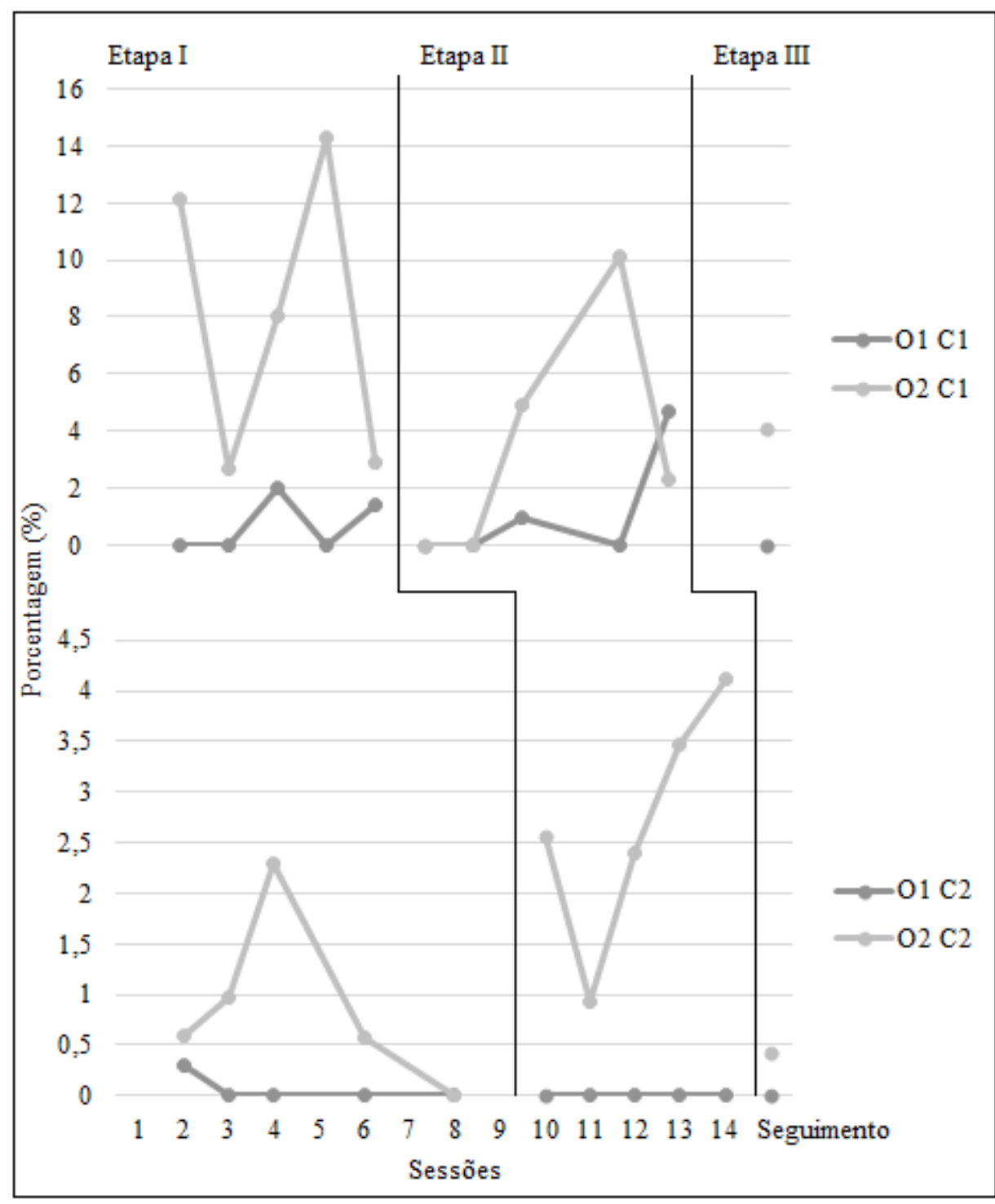

Figura 13. Porcentagens de ocorrência dos Os 1 e 2 durante a coleta 
Na Figura 13 constam as porcentagens dos Os 1 e 2 durante a coleta. Para ambos os clientes, trata-se de uma categoria com grandes oscilações. C1 emite mais Os2 que Os1, com exceção da última sessão da Etapa II, em que ocorrem mais Os1. A emissão de Os1 se mantém baixa durante toda a coleta.

C2 também emite mais Os2 do que Os1, sendo que Os1 ocorreram apenas na primeira sessão de coleta, não ocorrendo nas sessões seguintes em nenhum momento. Assim, observase a distância das linhas de $\mathrm{O} 1$ e $\mathrm{O} 2$ para C2, o que se sustenta durante toda a coleta. Há uma tendência crescente na emissão de Os2 a partir da segunda sessão de coleta após o workshop, o que não se mantém na coleta de seguimento.

\section{Dados da FAPIS}

A Tabela 5 contém as pontuações atribuídas entre 1 e 7 pelos participantes nos do is momentos do preenchimento: Antes do início do workshop (Pré) e um mês após a realização do mesmo (Pós). 
Tabela 5

Pontuação atribuídas pelos participantes às questões da FAPIS

\begin{tabular}{|c|c|c|c|c|c|c|c|c|c|}
\hline \multirow[b]{2}{*}{ Questões } & \multicolumn{2}{|c|}{ T1 } & \multicolumn{2}{|c|}{ T2 } & \multirow[b]{2}{*}{ Questões } & \multicolumn{2}{|c|}{ T1 } & \multicolumn{2}{|c|}{ T2 } \\
\hline & Pré & Pós & Pré & Pós & & Pré & Pós & Pré & Pós \\
\hline 1 & 6 & 6 & 3 & 5 & 24 & 6 & 7 & 5 & 7 \\
\hline 2 & 5 & 5 & 4 & 6 & 25 & 6 & 6 & 5 & 6 \\
\hline 3 & 7 & 5 & 5 & 5 & 26 & 5 & 5 & 3 & 3 \\
\hline 4 & 6 & 6 & 5 & 6 & 27 & 6 & 7 & 5 & 5 \\
\hline 5 & 5 & 6 & 6 & 7 & 28 & 3 & 6 & 3 & 4 \\
\hline 6 & 5 & 6 & 5 & 5 & 29 & 3 & 5 & 4 & 6 \\
\hline 7 & 5 & 6 & 6 & 5 & 30 & 7 & 7 & 5 & 6 \\
\hline 8 & 6 & 6 & 4 & 5 & 31 & 3 & 5 & 2 & 4 \\
\hline 9 & 7 & 5 & 3 & 6 & 32 & 2 & 5 & 5 & 5 \\
\hline 10 & 7 & 7 & 6 & 7 & 33 & 6 & 6 & 5 & 6 \\
\hline 11 & 5 & 6 & 4 & 6 & 34 & 6 & 6 & 4 & 6 \\
\hline 12 & 5 & 6 & 3 & 5 & 35 & 5 & 6 & 6 & 6 \\
\hline 13 & 7 & 7 & 6 & 7 & 36 & 2 & 3 & 2 & 3 \\
\hline 14 & 7 & 6 & 4 & 4 & 37 & 6 & 7 & 5 & 6 \\
\hline 15 & 7 & 7 & 5 & 7 & 38 & 6 & 7 & 5 & 6 \\
\hline 16 & 7 & 7 & 4 & 5 & 39 & 6 & 6 & 6 & 6 \\
\hline 17 & 5 & 7 & 3 & 6 & 40 & 4 & 5 & 2 & 4 \\
\hline 18 & 5 & 7 & 3 & 5 & 41 & 7 & 7 & 7 & 7 \\
\hline 19 & 4 & 5 & 5 & 6 & 42 & 7 & 7 & 6 & 6 \\
\hline 20 & 5 & 6 & 5 & 6 & 43 & 5 & 7 & 6 & 6 \\
\hline 21 & 5 & 7 & 4 & 6 & 44 & 3 & 6 & 4 & 6 \\
\hline 22 & 7 & 1 & 4 & 3 & 45 & 5 & 5 & 6 & 4 \\
\hline 23 & 5 & 7 & 4 & 5 & 46 & 1 & 5 & 6 & 6 \\
\hline
\end{tabular}

Para a T1, 25 questões apresentaram diferença positiva (ou seja, apresentaram aumento após o workshop), quatro questões apresentaram diferença negativa e 17 questões tiveram a mesma pontuação em ambos os momentos de preenchimento da escala. Para o T2, 31 questões apresentaram aumento do primeiro para o segundo momento de preenchimento da escala, 12 questões mantiveram pontuações iguais entre os momentos e três tiveram diferença negativa.

Foram calculadas as somas e as médias de todas as pontuações em cada momento. Esses dados estão apresentados na Tabela 6. 
Tabela 6

Somas e médias das pontuações atribuídas pelos Terapeutas pré e pós-workshop

\begin{tabular}{rcc|cc} 
& \multicolumn{2}{c|}{ T1 } & \multicolumn{2}{c}{ T2 } \\
\cline { 2 - 5 } & Pré & Pós & Pré & Pós \\
\hline Total & 243 & 273 & 208 & 252 \\
Média & 5,3 & 5,9 & 4,5 & 5,5 \\
\hline
\end{tabular}

Um mês após a intervenção, a pontuação total da T1 aumentou em 30 pontos, e a média aumentou 0,6 ponto. A pontuação do T2 subiu 44 pontos no segundo momento do preenchimento da escala, e a média subiu um ponto. Foram selecionadas as questões que apresentaram maior diferença entre os momentos, apresentadas nas Tabelas 7 e 8.

Tabela 7

Questões cujas diferenças de pontuação pré e pós-workshop foram $\geq 2$

\begin{tabular}{cc|cc} 
& T1 & & T2 \\
\cline { 2 - 3 } Questões & Diferença pré e pós & Questões & Diferença pré e pós \\
\hline $\mathbf{4 6}$ & $\mathbf{4}$ & $\mathbf{9}$ & 3 \\
$\mathbf{2 8}$ & $\mathbf{3}$ & $\mathbf{1 7}$ & 3 \\
$\mathbf{3 2}$ & $\mathbf{3}$ & $\mathbf{2}$ & 2 \\
$\mathbf{4 4}$ & $\mathbf{3}$ & $\mathbf{1 1}$ & 2 \\
$\mathbf{1 7}$ & $\mathbf{2}$ & $\mathbf{1 2}$ & 2 \\
$\mathbf{1 8}$ & $\mathbf{2}$ & $\mathbf{1 5}$ & 2 \\
$\mathbf{2 1}$ & $\mathbf{2}$ & $\mathbf{1 8}$ & 2 \\
$\mathbf{2 3}$ & $\mathbf{2}$ & $\mathbf{2 1}$ & 2 \\
$\mathbf{2 9}$ & $\mathbf{2}$ & $\mathbf{2 4}$ & 2 \\
$\mathbf{3 1}$ & $\mathbf{2}$ & $\mathbf{3 1}$ & 2 \\
$\mathbf{4 3}$ & $\mathbf{2}$ & $\mathbf{3 4}$ & 2 \\
& & $\mathbf{4 0}$ & 2 \\
& & $\mathbf{4 4}$ & 2 \\
& &
\end{tabular}


As questões que coincidiram em apresentar diferenças positivas maiores ou iguais a 2 para ambos os terapeutas foram as questões 44, 17, 18, 21, 29 e 31. As questões estão apresentadas a seguir:

17 - Eu estou aberto sobre o impacto que meus clientes causam em mim

18 - Eu experiencio fortes emoções durante minhas sessões

21 - Eu me preocupo sobre o que meus clientes estão tentando dizer em contraste com o que eles estão realmente dizendo

29 - Eu tenho conversas sinceras e abertas sobre como a terapia está indo

31- Com clientes, eu não preciso ser sempre suporte a eles. Eu posso expressar desapontamento, braveza, assim como frustração

44 - Eu vejo meus riscos e vulnerabilidades em sessão como importante para a melhora do cliente

Algumas questões apresentaram diferença negativa entre pré e pós, ou seja, tiveram pontuações maiores antes da Intervenção II do que a pontuação atribuída um mês após a mesma. Essas questões e as respectivas diferenças estão apresentadas na Tabela 9.

\section{Tabela 8}

Questões cujas diferenças de pontuação pré e pós-workshop foram $\leq-1$

\begin{tabular}{|c|c|c|c|}
\hline \multicolumn{2}{|c|}{ T1 } & \multicolumn{2}{|c|}{$\mathbf{T} 2$} \\
\hline Questões & Diferença & Questões & Diferença \\
\hline 14 & -1 & 7 & -1 \\
\hline 3 & -2 & 22 & -1 \\
\hline 9 & -2 & 45 & -2 \\
\hline 22 & -6 & & \\
\hline
\end{tabular}

As questões que apresentaram diferença negativa foram as seguintes:

3 - Eu estou em contato com meus valores enquanto terapeuta

7 - Eu sei como aplicar o behaviorismo de forma significativa na relação terapêutica 
9 - Eu reconheço melhoras sutis nos comportamentos dos meus clientes em sessão

14 - Eu sou guiado por princípios sobre como me relaciono com meus clientes

22 - Durante as sessões, meu comportamento não está controlado por ansiedade e raiva

45 - Eu me sinto exausto depois de uma sessão terapêutica

Todas as questões constantes no instrumento podem ser consultadas no Anexo 1.

\section{Discussão}

Considerando os dados apresentados, é possível notar que alguns resultados seguiram a tendência esperada, enquanto outros são oscilantes e alguns seguiram tendência oposta à esperada após o workshop. Esses dados serão discutidos adiante, mas antes, serão apresentadas e discutidas algumas dificuldades e limitações encontradas durante o desenvolvimento da pesquisa.

Uma dificuldade importante deste estudo refere-se ao delineamento adotado. Embora o delineamento de sujeito único seja uma ferramenta eficiente para demonstrar relações causais entre intervenção e mudanças de comportamento, intervenções podem ser efetivas para um indivíduo, mas não para outro (Nock, Michel \& Photos, 2008). Dessa forma, pode-se observar que as díades participantes desse estudo apresentaram alguns resultados opostos. Não obstante esses resultados poderem ser interpretados à luz da conceituação de caso, resultados congruentes trariam mais força à hipótese aqui considerada. Além disso, a intervenção aqui estudada traz limitações adicionais ao delineamento, uma vez que requer considerável organização e planejamento, e um número mínimo de participantes. Isso implica na inviabilidade de inserir a intervenção em momentos diferentes no tempo para cada participante, ou mesmo seu adiamento em caso de instabilidade das variáveis dependentes. Dessa forma, em caso de desistência ou falta de clientes às sessões, não é possível adaptar o delineamento a novas condições, o que implicou na participação de apenas dois terapeutas 
participantes. Para pesquisas futuras, seria recomendável iniciar a coleta com um número maior de participantes - pelo menos dois participantes para cada linha de base, de forma a reduzir consideravelmente as chances de perder dados devido a desistências.

Os participantes dessa pesquisa, por se tratarem de uma recém-formada e de um aluno de graduação, têm pouca experiência clínica, o que pode ter alguma influência nos resultados, dado que terapeutas experientes têm maior variabilidade em seu repertório clínico e ficam mais sob controle do que acontece nas sessões do que terapeutas iniciantes (Donadone, 2004). Seria interessante replicar esse estudo com terapeutas experientes, para verificar se os resultados diferem em função do nível de experiência do terapeuta participante. Essa alternativa poderia indicar que o workshop de forma isolada não é suficiente para a consolidação de um repertório adequado por parte do terapeuta para a FAP, já que, em caso contrário, o repertório do terapeuta anterior ao workshop não seria uma variável importante.

Outra limitação refere-se aos instrumentos utilizados. A escala de autorrelato FAPIS consiste em um instrumento que ainda não foi validado e que estava em processo de alterações quando a coleta teve início. Por isso, há muitas afirmações ambíguas ou sem relação clara com as regras da FAP.

O instrumento FAPRS vem sendo frequentemente utilizado em pesquisas clínicas sobre FAP (Busch et al., 2009; Callaghan, Summers \& Weidman, 2003; Del Prette, 2011; Dias \& Silveira, 2016; Freitas, 2011; Geremias, 2014; Lizarazo, Muñoz-Martínez, Santos \& Kanter, 2015; Mangabeira, 2014; Meurer, 2011; Oshiro, 2011; Villas-Bôas, 2015), porém, para o objetivo do presente estudo, seria de grande utilidade se existissem instrumentos adicionais que, além da avaliação quantitativa dos comportamentos, realizasse m uma avaliação qualitativa. É possível, por exemplo, que tenham acontecido Regras 2, mas que não tenham sido eficazes, sem evocar, portanto, CCRs do cliente. O mesmo se aplica aos TRBs, que podem ou não reforçar comportamentos de melhora, a depender de variáveis do cliente, mas também da eficácia das consequenciações providas pelo terapeuta. A interpretação dos dados 
poderia ser complementada por um instrumento que avaliasse a qualidade das intervenções realizadas pelo terapeuta. Nesse sentido, um instrumento está sendo desenvolvido. Trata-se da FAP Competency Scale (Kanter, Villas-Bôas \& Sullivan-Singh, 2016), uma escala de avaliação qualitativa relativa às competências desejáveis ao terapeuta FAP, o que seria útil nesse estudo como uma medida complementar dos efeitos do treino de terapeutas. Contudo, a escala se encontra em fase de desenvolvimento e de testes, não tendo ocorrido sua finalização ou publicação até o momento do encerramento desta pesquisa.

Além disso, o instrumento FAPRS tem como unidade de análise uma fala delimitada pela fala seguinte da outra pessoa. Dessa forma, a utilização desse instrumento pode ter prejudicado a análise especialmente da Díade 1, na qual a cliente fazia longas falas que poderiam conter diversas categorias, mas que resultam em apenas uma, seguindo a hierarquia definida pelo instrumento. Assim, é possível que tenha havido mais ocorrências de categorias como O1, O2, CCR1, e que elas tenham sido contabilizadas como outra categoria também presente na mesma fala e com maior prioridade segundo a hierarquia.

Alguns cuidados foram levados em consideração nesta pesquisa com a intenção de excluir ou de reduzir possíveis vieses. O fato de a pesquisadora (e categorizadora) não ser a terapeuta é um cuidado nesse sentido. Porém, essa condição produziu algumas dificuldades, como com relação à compreensão precisa da conceituação de caso pela pesquisadora. A pesquisadora esclareceu dúvidas sobre as conceituações de caso com os terapeutas, procurando evitar influenciar na formulação delas. Nesse sentido, a alta concordância encontrada na aferição reduz a possibilidade de vieses de interpretação da pesquisadora, já que os aferidores tiveram acesso apenas às sessões específicas a aferir, a respectiva conceituação de caso, e não houve treino específico para a aferição.

Segundo Nock, Michel e Photos (2008), a limitação mais frequentemente citada em discussões de delineamentos de sujeito único é a falta de generalidade dos efeitos obtidos, o 
que também se verifica na presente pesquisa, considerando que esta conta com apenas dois casos e que alguns resultados diferem entre si.

Outra limitação diz respeito à dificuldade em medir melhoras na vida diária do cliente. O objetivo maior da terapia consiste em propiciar aos clientes que os comportamentos de melhora passem a fazer parte de seu repertório, tornando-os aptos a emiti-los fora das sessões. No entanto, ao utilizar o instrumento FAPIS, é possível apenas medir os relatos desses comportamentos, o que é uma medida indireta e que pode ser imprecisa. A utilização de instrumentos adicionais para os comportamentos externos à sessão poderia fortalecer a hipótese de melhora do cliente.

Além disso, a escassez de estudos voltados para a investigação da eficácia de treinos de terapeutas impossibilita a comparação dos resultados obtidos neste estudo.

Essas limitações e dificuldades apresentadas podem nortear pesquisas futuras no sentido de evitá-las ou de contorná-las, quando possível.

Sobre a conceituação dos casos faz-se necessário tecer algumas considerações. A primeira é que ela não fez parte dos objetivos e atividades do workshop de Nível 1, aparecendo como objetivo somente no Nível 2, quando já teriam sido aprendidas as habilidades terapêuticas. No caso da Díade 1, dentre os CCRs2, estavam comportamentos relacionados à expressão de emoções e assertividade, como realizar pedidos à terapeuta mesmo que houvesse a possibilidade da negativa da mesma; à expressão de emoções, como raiva, medo e tristeza, e relatar de aceitação das mesmas. Outro CCR2 corresponde à cliente relatar ou emitir comportamentos indicativos de aceitação de novas contingências reforçadoras, não condizentes com a sua religião, que compreende valores considerados conservadores, como abstinência sexual para solteiros, regras específicas sobre vestimenta e sobre a aparência, entre outros. O relato da cliente envolvendo a oscilação entre culpa e aceitação com relação a esses comportamentos não condizentes aos preceitos da igreja era considerado um CCR1. 
Ao início da coleta, C1 vivia um relacionamento amoroso casual com um colega, que lhe provia reforçadores positivos como atenção social e sexo, mas não condizia com sua religião, gerando um conflito, uma vez que ela relatava não poder participar das atividades da igreja enquanto estivesse envolvida nes sa relação, e que tanto a igreja como essa relação eram importantes para ela, não sendo possível conciliá-las.

Considerando esse conflito, dois dados encontrados na literatura poderiam direcionar a intervenção do terapeuta: (1) a American Psychological Association (2006) define que a Decisão Clínica deve levar em consideração as características, valores e contexto do paciente, ou seja, esses aspectos devem ser respeitados para garantir melhores resultados da terapia e (2) segundo Skinner (1965), "Quando analisamos uma situação cuidadosamente durante a tomada de uma decisão, possivelmente aumentamos a probabilidade de que a resposta eventualmente realizada atingirá o máximo reforçamento" (p. 244), o que revela a necessidade de se analisar cuidadosamente as consequências de respostas possíveis para que o cliente possa tomar decisões que the sejam mais reforçadoras.

Presume-se, com essa conceituação de caso que T1, considerando a percepção do alto valor reforçador de ambas as situações, procurou trabalhar de forma a integrá-las. Entretanto, essa integração não foi possível, já que viver uma relação casual não condizia com os valores religiosos da cliente, o que se confirma pelo término dessa relação no período da terapia em que não houve coleta de dados, entre as Etapas II e III.

Ao contrário do esperado nesse estudo, no caso da Díade 1 a emissão de CCRs2 diminuiu ao longo da coleta e aumentou a emissão de CCRs1 na Etapa II. Primeiramente, é importante destacar que durante toda a coleta, as porcentagens de CCRs2 foram maiores do que as de CCRs1, ou seja, em todos os momentos houve mais comportamentos de melhora do que comportamentos "problema". O aumento de CCRs1 pode ter resultado do fato de que, após a Intervenção II, a relação amorosa de C1 teve maior enfoque na terapia, o que certamente aumenta a frequência de relatos que envolvem oscilação entre culpa e aceitação. 
Esses comportamentos continuaram sendo considerados por $\mathrm{T} 1$ como comportamentos problema (CCRs1 - conforme indicado na conceituação de caso elaborada por T1), embora tenham feito parte da resolução do conflito. Pode-se notar pela Figura 4 que a Etapa III tem a média mais baixa de CCRs1, o que condiz com a hipótese de que conciliar a religião e o relacionamento casual era inviável, já que nessa etapa, o relacionamento já havia terminado.

A Díade 2 apresentou particularidades diferentes. A conceituação de caso de T2 era parte dos requisitos da supervisão clínica, e foi influenciada pela supervisão e pelas avaliações da supervisora no decorrer do curso, o que pode explicar porque a falta de treino de conceituação de caso durante o workshop não tenha sido um problema para T2.

Sobre as categorias $\mathrm{O} 1$ e $\mathrm{O} 2$, a Figura 13 mostra que para $\mathrm{C} 1$, elas oscilam durante a coleta, embora $\mathrm{O} 2$ esteja predominantemente acima de $\mathrm{O} 1$ (com exceção da última sessão da Etapa II). Não há relação clara entre a Intervenção II e as categorias O1 e O2 de C1. Isso pode decorrer do fato de a terapia não as ter como foco, não havendo intervenções sistemáticas que pudessem influenciar em sua frequência. Para C2, há ocorrência de $\mathrm{O} 1$ apenas na primeira sessão da coleta, e $\mathrm{O} 2$ oscila na primeira etapa, apresentando tendência crescente na segunda. Esses dados podem indicar algum efeito da intervenção sobre a emissão de Os2, e pode indicar generalização de comportamentos de melhora para os ambientes do dia a dia.

Com relação à Regra 2, seria de se esperar um aumento após o workshop, que tem seu foco na evocação e consequenciação de CCRs. Contudo, conforme é possível notar na Figura 6, o aumento na Etapa II foi muito discreto para ambos os terapeutas. Isso indica que a Intervenção II não teve o efeito que seria esperado sobre essa habilidade terapêutica, embora seja possível observar pela Figura 9 que a emissão de comportamentos de melhora foi maior após o workshop para a Díade 2, o que sugere maior eficácia das evocações e/ou consequenciações emitidas pelo terapeuta. Com relação à habilidade de prover consequências eficazes, a Figura 12 mostra que, para a Díade 1, T1 passou a prover mais consequências para os CCRs1 após a intervenção. Já com relação aos CCRs2 e TRBs2, a Figura 10 mostra que 
para a Díade 1 há maior atenção do terapeuta em reconhecer os CCRs2 e também maior frequência de consequenciações, o que se faz fundamental para que haja a modelagem desse repertório. Para a Díade 2, não se observa efeito claro do workshop sobre a relação entre CCR1 e TRB1, conforme se observa na Figura 12, até porque a porcentagem de ambas as categorias é muito baixa.. Dessa forma, T2 já se atentava e provia consequências para CCRs1 com eficiência durante toda a coleta, não existindo muita margem para melhorar um repertório já bem instalado nos poucos casos em que ocorria CCR1.

Já sobre os CCRs2, a Figura 10 mostra que ao início da Etapa II ocorre a aproximação das linhas de CCR2 e TRB2 (embora TRB2 se mantenha sempre abaixo de CCR2), mas com distanciamento acentuado nas duas últimas sessões dessa etapa e também na Etapa de Seguimento. É interessante notar que ainda que haja essa diminuição de TRB2, há uma clara tendência crescente de CCRs2, o que indica o fortalecimento desse repertório para C2, isto é, mesmo que o terapeuta não estivesse consequenciando com maior frequência, esses comportamentos de melhora passaram a ser emitidos em porcentagem maior ao longo da coleta. Há ainda que se lembrar de que, para a Díade 2, parece haver maior relação entre o CCR2 e a Regra 2 do que o CCR2 e sua consequência, o TRB2. Esse parece ser um indicador de que a evocação pela Regra 2 controlou mais a emissão de CCR2 de C2 do que a sua consequenciação pelo terapeuta (TRB2).

Os dados, portanto, indicam que o principal efeito do workshop para ambos os participantes foi a melhora no reconhecimento e na eficiência ao prover consequências para os comportamentos de melhora emitidos pelo cliente, habilidade que é essencial para que ocorra a aprendizagem desses comportamentos (Catania, 1999) pelo cliente e para que haja bons resultados para uma terapia FAP, além de indicar também o efeito positivo do workshop na evocação de T2, especialmente para os CCRs1.

Esses dados vão ao encontro dos obtidos pela escala de auto relato FAPIS, na qual a maioria das afirmações que apresentaram diferença positiva após o treino (Tabela 8) está 
relacionada à expressão de emoções do terapeuta durante a sessão. Essa habilidade é especialmente útil ao terapeuta como forma de prover consequências (TRB1 e TRB2) para os comportamentos "problema" e de melhora do cliente em sessão, recorrendo à autorrevelação de suas emoções para descrever o impacto gerado no terapeuta pelo comportamento do cliente (e assim, reforçar ou punir um CCR).

Outra utilidade da autorrevelação do terapeuta pode ser a de fazer paralelos entre o impacto que o cliente causa no terapeuta e o que ele impacta nas pessoas próximas a ele (Regra 5), propiciando a generalização do comportamento do cliente.

Além disso, após o treino, ambos os terapeutas atribuíram pontuações mais altas na questão 21, que está relacionada à tentativa do terapeuta em identificar a função do relato do cliente, e não apenas com o conteúdo (topografia), algo imprescindível para a cond ução FAP, segundo a qual se deve avaliar os comportamentos do cliente funcionalmente, em vez de olhar somente para a forma ou a topografia do comportamento (Kohlenberg \& Tsai, 1991).

A única questão que teve diferença negativa em comum para ambos os terapeutas foi a 22 ("Durante as sessões, meu comportamento não está controlado por ansiedade e raiva"). Trata-se de uma questão ambígua, uma vez que é desejável que o terapeuta esteja atento e fique sob controle de seus comportamentos encobertos, que podem incluir comportamentos relacionados à ansiedade e raiva. Contudo, a questão não discrimina a forma como o terapeuta se comporta em relação ao cliente frente a esses sentimentos.

Outra questão ambígua é a 45 ("Eu me sinto exausto depois de uma sessão terapêutica"), pois, por um lado, à medida que o terapeuta se coloca intensamente na relação terapêutica, lidar com as emoções ali manifestadas pode demandar mais do terapeuta. Porém, não é desejável que a terapia seja exaustiva.

As Questões 7 e 9 ("Minha conc eituação de caso inclui comportamentos específicos que vejo em sessão" e "Eu posso utilizar tratamentos e instrumentos estruturados de forma autêntica e vinculada com meu cliente") podem expressar dificuldades dos terapeutas durante 
sua prática clínica, sendo uma das questões pertinente ao conhecimento teórico de Análise do Comportamento e a outra, relacionada à Regra 1, que, como dito anteriormente, não é o principal foco da Intervenção.

Merece ainda análise a comparação destas duas psicoterapias analíticas funcionais com outras desenvolvidas no mesmo laboratório. Nas pesquisas de Oshiro (2011), de Geremias (2014), de Mangabeira (2015) e de Villas-Bôas (2015), em que os terapeutas possuíam experiência consideravelmente maior com a FAP do que os terapeutas deste estudo, além de terem compromisso com a obtenção de bons dados de pesquisa, a aplicação da FAP se deu de forma mais consistente, permitindo a obtenção de efeitos mais claros. Entretanto, houve similaridade em um resultado: CCRs2 foram mais frequentes do que CCRs1, tendo ocorrido para C2 um claro aumento nos comportamentos de melhora. E esse resultado pode ser considerado bom, já que a FAP e os princípios de aprendizagem preconizam a aprendizagem por reforçamento positivo à aprendizagem por extinção ou punição, mesmo que leve.

\section{Considerações finais}

O objetivo do presente trabalho foi o de verificar se o treino em FAP por meio do workshop instala no terapeuta habilidades necessárias para o seguimento das regras da FAP. Nesse sentido, é possível concluir que o treino atingiu parcialmente seus objetivos, dado que os resultados esperados previam que ambos os clientes passassem a emitir mais CCR2 após o treino do terapeuta, o que aconteceu apenas para $\mathrm{C} 2$, enquanto $\mathrm{C} 1$ apresentou tendência oposta.

É importante destacar que, durante toda a coleta, foi observado para ambos os terapeutas maior sensibilidade para os comportamentos "problema" comparativamente aos comportamentos de melhora, mas que, no entanto, passaram a ficar mais sensíveis aos CCRs2 após o workshop. Esse dado é importante por indicar que o treino favoreceu o seguimento da Regra 3 pelos terapeutas participantes. O seguimento da Regra 2 também foi favorecido, mas 
apenas em pequena escala para o Terapeuta 2. Porém, convém considerar esses resultados com cautela, pois eles se referem a apenas duas díades de terapeuta e cliente. Mais pesquisas nesse sentido mostram-se necessárias, preferencialmente com maior número de participantes, para verificar se esses resultados são replicáveis. 


\section{REFERÊNCIAS}

American Psychological Association (2006). Evidence-based practice in psychology: APA presidential task force on evidence-based practice. American Psychologist, 61, 271-285.

Brandão, M. Z. da S. (1999). Terapia comportamental e análise funcional da relação terapêutica: estratégias clínicas para lidar com comportamentos de esquiva. Revista Brasileira de Terapia Comportamental e Cognitiva, 1(2), 179-187.

Busch, A. M., Kanter, J. W., Callaghan, G. M. Baruch, D. E., Weeks, C. E. \& Berlin, K. S. (2009). A Micro-Process Analysis of Functional Analytic Psychotherapy's Mechanism of Change. Behavior Therapy, 40, 280-290.

Callaghan, G., M. (2006). Functional Analytic Psychotherapy and Supervision. International Journal of Behavioral Consultation and Therapy, 2(3), 416-431.

Callaghan, G. M., \& Follette, W. C. (2008). FAPRS Manual: Manual for the Functional Analytic Psychotherapy Rating Scale. The Behavior Analyst Today. 9(1), 57-97.

Callaghan, G. M., Summers, C. J., \& Weidman, M. (2003). The treatment of histrionic and narcissistic personality disorder behaviors: A single-subject demonstration of clinical improvement using functional analytic psychotherapy. Journal of contemporary psychotherapy, 33(4), 321-339.

Catania, A. C. (1999). Aprendizagem: Comportamento, linguagem e cognição (4. ed.). Porto Alegre, RS: Artmed.

Cohen, J. (1960). A coefficient of agreement for nominal scales. Educational and Psychological Measurement, 20, 37-46.

Del Prette, G. Objetivos Analíticos-comportamentais e estratégias de intervenção nas interações com a criança em duas sessões de duas renomadas terapeutas infantis (Tese de Doutorado). Instituto de Psicologia, Universidade de São Paulo, São Paulo.

Dias, A. Y. M. S., \& Silveira, J. M. (2016). Comparação de duas intervenções no tratamento de um casal: $\mathrm{O}$ treino do comportamento vulnerável à punição. Acta Comportamentalia, 24(1), 61-77.

Donadone, J. C. (2004). O uso da orientação em intervenções clínicas por terapeutas comportamentais experientes e pouco experientes (Dissertação de mestrado). Instituto de Psicologia, Universidade de São Paulo, São Paulo. 
Follette, V. M. \& Batten, S. V. (2000). The role of emotion in psychotherapy supervision: a contextual behavioral analysis. Cognitive and Behavioral Practice, 7, 306-312.

Follette, W. C. \& Callaghan, G. M. (1995). Do as I do, not as I say: a behavior-analytic approach to supervision. Professional Psychology: Research and practice, 26(4), 413421.

Freitas, S. T. (2011). Efeitos de procedimentos focados na relação terapêutica sobre comportamentos geralmente descritos nos quadros de depressão (Dissertação de mestrado). Universidade Federal do Paraná, Curitiba.

Geremias, M. C. G. (2014). Manejo de esquivas emocionais na Psicoterapia Analítica Funcional: delineamento experimental de caso único (Dissertação de Mestrado). Instituto de Psicologia, Universidade de São Paulo, São Paulo.

Hartmann, D. P., Barrios, B. A., \& Wood, D. D. (2004). Principles of behavioral observation. Comprehensive handbook of psychological assessment, 3, 108-127.

Haworth, K., Kanter, J. W., Tsai, M., Kuczynski, A. M., Rae, J. R. \& Kohlenberg, R. J. (2015). Reinforcement matters: A preliminary, laboratory-based component-process analysis of a Functional Analytic Psychotherapy's model of social connection. Journal of Contextual Behavioral Science, 4, 281-291.

Kanter, J. W., Villas-Bôas, A., \& Sullivan-Singh, S. (2016). FAP Competency Scale. University of Washington: Unpublished manuscript.

Kanter, J. W., Tsai, M., Holman, G., \& Koerner, K. (2013). Preliminary data from a randomized pilot study of web-based functional analytic psychotherapy therapist training. Psychotherapy, 50(2), 248-255.

Kazdin, A. E. (2002). Research design in clinical psychology. Boston: Allyn and Bacon.

Kohlenberg, R. J., \& Tsai, M. (1991). Functional analytic psychotherapy: A guide for creating intense and curative therapeutic relationships. NY: Plenum.

Kohlenberg, R. J. \& Tsai, M. (2001). Aplicação clínica da psicoterapia analítica funcional. In Psicoterapia analítica funcional: criando relações terapêuticas intensas e curativas (pp. 19-50). Santo André, SP: ESETec. 
Kratochwill, T. R., Hitchcock, J. H., Horner, R. H., Levin, J. R., Odom, S. L., Rindskopf, D. M. \& Shadish, W. R. (2012). Single-case intervention research design standards. Remedial and Special Education, 34(1), 26-38.

Lepienski, A. F. (2015). Relações entre uma supervisão em psicoterapia analítica funcional e as respostas de uma terapeuta e sua cliente em sessão. (Dissertação de Mestrado). Universidade Federal do Paraná, Curitiba.

Lizarazo, N. E., Muñoz-Martínez, A. M., Santos, M. M., \& Kanter, J. W. (2015). A withinsubjects evaluation of the effects of functional analytic psychotherapy on in-session and out-of-session client behavior. The Psychological Record, 65(3), 463-474.

Machado, P. P. P., Beutler, L. E. \& Greenberg, L. (1999). Emotion recognition in psychotherapy: impact of therapist level of experience and emotional awareness. Journal of Clinical Psychology, 55(1), 39-57.

Mangabeira, V. (2014). Efeitos da sinalização de intervenções na psicoterapia analítica funcional (Tese de Doutorado). Instituto de Psicologia, Universidade de São Paulo, São Paulo.

Meurer, P. H. (2011). Efeito da apresentação de feedback no comportamento do terapeuta de evocar e responder aos comportamentos clinicamente relevantes (Dissertação de mestrado). Universidade Federal do Paraná, Curitiba.

Nock, M. K., Michel, B. D. \& Photos, V. I. (2008). Single-case research designs. In D. McKay (Ed.), Handbook of Research Methods in Abnormal and Clinical Psychology (pp. 337-350). New York, Estados Unidos: SAGE.

Oshiro, C. K. B. (2011). Delineamento experimental de caso único: a Psicoterapia Analítica Funcional com dois clientes difíceis (Tese de Doutorado). Departamento de Psicologia Clínica, Instituto de Psicologia, Universidade de São Paulo, São Paulo.

Skinner, B. F. (1965). Science and human behavior. New York, NY: Macmillan.

Skinner, B.F. (1982). Sobre o Behaviorismo. São Paulo: Cultrix.

Silveira, J. M., Callaghan, G. M., Stradioto, A., Maeoka, B. E., Maurício, M. N. \& Goulin, P. (2009). Efeitos de um treino em Psicoterapia Analítica Funcional sobre a identificação feita pelo terapeuta de comportamentos clinicamente relevantes de seu cliente. Revista Brasileira de Terapia Comportamental e Cognitiva, 11(2), 346-365. 
Smith, T. B., Holt-Lunstad, J., \& Layton, J. B. (2010). Social relationships and mortality risk: A Meta-Analytic Review. PLoS Med, 7(7), e1000316.

Sousa, A. C. A. \& Vandenberghe, L. (2007). Possibilidades da FAP como método de supervisão de terapeutas com clientes borderlines. Revista Brasileira de Terapia Cognitiva e Comportamental, 9(1), 1-11.

Suen, H. K. \& Ary, D. (1989). Analyzing quantitative behavioral observation data. Lawrence Erlbaum Associates: New Jersey.

Tsai, M., Kohlenberg, R., Kanter, J., Kohlenberg, B., Follette, W. \& Callaghan, G. (Eds.) (2009). A guide to functional analytic psychotherapy: Awareness, courage, love and behaviorism in the therapeutic relationship. New York: Springer. doi:10.1007/978-0387-09787-9

Tsai, M., Callaghan, G. M. \& Kohlenberg, R. J. (2013). The use of Awareness, Courage, Therapeutic Love and Behavioral Interpretation in Functional Analytic Psychotherapy. Psychotherapy, 50 (3), 366-370. DOI: 10.1037/a0031942

Vandenberghe, L. \& Pereira, M. B. (2005). O papel da intimidade na relação terapêutica: uma revisão teórica à luz da análise clínica do comportamento. Psicologia: Teoria e Prática, $7(1), 127-136$.

Villas-Bôas, A. (2015). Efeitos de análises de contingências sobre Comportamentos Clinicamente Relevantes e sobre mudanças extra sessão (Tese de Doutorado). Departamento de Psicologia Clínica, Instituto de Psicologia, Universidade de São Paulo, São Paulo.

Wetterneck, C. T., Lee, E. B., \& Holman, G. I. (2016). Validation of the Functional Analytic Psychotherapy Scale for Therapists. Manuscrito em preparação.

Wielenska, R. C. \& Oshiro, C. K. B. (2012). FAP group supervision: reporting educational experiences at the University of São Paulo, Brazil. International Journal of Behavioral Consultation and Therapy, (2-3), 177-181. 


\section{ANEXOS}

\section{ANEXO 1 - Escala de Impacto da FAP (FAPIS)}

\section{Escala de impacto - FAP}

As frases abaixo dizem respeito a como você se sente em relação ao seu trabalho como terapeuta e como a terapia afeta você. Nós estamos interessados em como você se sente de forma geral em sua prática como terapeuta e seu papel profissional. Responda a cada uma das frases indicando o quanto você concorda ou discorda com ela. Escreva o número no espaço reservado, usando a seguinte escala:

$\begin{array}{ccccccc}1 & 2 & 3 & 4 & 5 & 6 & \begin{array}{c}7 \\ \begin{array}{c}\text { Concordo } \\ \text { fiscordo } \\ \text { fortemente }\end{array}\end{array} \\ & & & \text { Neutro } & & & \end{array}$

1) Eu corro riscos estratégicos e terapêuticos com meus clientes

2) Eu sou claro sobre como meus clientes podem melhorar seus relacionamentos

3) Eu estou em contato com meus valores enquanto terapeuta

4) Eu percebo minhas reações emocionais durante as sessões

5) Eu mostro como realmente sou para meus clientes

6) Eu sei como aplicar o behavioris mo de forma significativa na relação terapêutica

7) Minha conceituação de caso inclui comportamentos específicos que vejo em sessão

8) Eu reconheço melhoras sutis nos comportamentos dos meus clientes em sessão

9) Eu posso utilizar tratamentos e instrumentos estruturados de forma autêntica e vinculada com meu cliente

10)Eu experiencio meu trabalho como terapeuta como sendo pessoalmente significativo

11)Eu desafio meus clientes a darem o melhor de si

12)Eu desafio meus clientes de formas que eles não gostam quando eu acho que é para o melhor deles

13)Meu trabalho como psicóloga mudou a forma como eu vejo o mundo

14)Eu sou guiado por princípios sobre como me relaciono com meus clientes 
15)Eu me preocupo sobre como meu comportamento afeta meus clientes

16)Eu tomo cuidado para não reforçar comportamentos inadequados

17)Eu estou aberto sobre o impacto que meus clientes causam em mim

18)Eu experiencio fortes emoções durante minhas sessões

19)Eu me sinto ansioso sobre minhas emoções durante a terapia

20)Eu me preocupo sobre como minhas emoções podem afetar o progresso do meu cliente

21)Eu me preocupo sobre o que meus clientes estão tentando dizer em contraste com o que eles estão realmente dizendo

22)Durante as sessões, meu comportamento não está controlado por ansiedade e raiva

23)Eu sinto um profundo vínculo com meus clientes

24)Eu sou genuíno em minhas conversas com meus clientes

25)Eu digo coisas difíceis de serem ditas aos meus clientes

26)Eu sou controlado por regras na forma de me colocar em todas as sessões

27)Eu sou flexível na forma de me colocar em sessão

28)Eu estou aberto a todas as minhas experiências em sessão

29)Eu tenho conversas sinceras e abertas sobre como a terapia está indo

30)Eu sou emocionalmente expressivo com meus clientes

31)Com clientes, eu não preciso ser sempre suporte a eles. Eu posso expressar desapontamento, braveza, assim como frustração

32) Eu verifico com meu cliente sobre o que a terapia significa para ele

33)Eu sou flexível com meus clientes

34)Eu estou disposto a experienciar as emoções de meus clientes

35)Eu utilizo muita energia emocional quando estou na sessão com um cliente

36)Eu estou confiante de que consigo analisar e entender qualquer comportamento

37)Eu sinto compreensão por meus clientes

38)Eu me sinto próximo de meus clientes

39) $\mathrm{Eu}$ sou honesto e atento às escolhas que faço em meus relacionamentos com clientes

40)Eu sou confiante em minha habilidade de pressionar um cliente de forma terapeuticamente efetiva

41)Eu valorizo a diversidade de histórias e origens das pessoas

42) Eu sinto empatia por clientes 
43)Trabalhar como psicólogo me levou a colocar mais ênfase (importância, cuidado e amparo) em meus próprios relacionamentos interpessoais

44)Eu vejo meus riscos e vulnerabilidades em sessão como importante para a melhora do cliente

45)Eu me sinto exausto depois de uma sessão terapêutica

46)Eu tenho compreensão por mim mesmo 


\section{ANEXO 2 - TERMO DE CONSENTIMENTO LIVRE E ESCLARECIDO - CLIENTE}

Prezado cliente,

Somos estudante e professora de pós-graduação do Laboratório de Terapia Comportamental do Instituto de Psicologia da Universidade de São Paulo e estamos estudando as habilidades terapêuticas e sua influência na terapia.

Para isso, solicitamos sua colaboração voluntária para participar de um projeto de pesquisa de mestrado, aprovado pelo Comitê de Ética em Pesquisa com Seres Humanos do Instituto de Psicologia da USP (CEPH-IPUSP), sob o número do processo: 33656014.3.0000.5561. O termo de consentimento livre e esclarecido é redigido em duas vias, sendo que uma via ficará em seu poder e outra com o pesquisador.

O CEPH-IPUSP é credenciado no Conselho Nacional de Ética em Pesquisa (CONEP) e fica localizado na Av. Professor Mello Moraes, no. 1.721 - Bloco G Sala 27 - Cidade Universitária - São Paulo/SP. O horário de atendimento ao público é de segunda a sexta-feira das $9 \mathrm{~h} 30$ às $12 \mathrm{~h}$ e das $14 \mathrm{~h}$ às $16 \mathrm{~h}$. O e-mail para contato é ceph.ip@usp.br e o telefone (11) 3091-4182.

Para que você possa decidir se pode colaborar conosco, procuramos esclarecer resumidamente, a seguir, o que será feito. Se depois de ler, você tiver dúvidas e quiser esclarecimentos, estaremos à sua disposição.

\section{Justificativa, objetivos e procedimentos que serão utilizados na pesquisa:}

Nossa pesquisa consiste na cond ução de um atendimento psicoterápico, com sessões semanais de 50 minutos, conduzidas de acordo com os preceitos da Psicoterapia Comportamental e da Psicoterapia Analítica Funcional (FAP). A FAP 
vem sendo desenvolvida e estudada ao longo dos anos e têm recebido grande reconhecimento na área nacional e internacional da Análise do Comportamento. No entanto, há aspectos da FAP ainda a serem investigados, para que se entenda melhor quais são as habilidades específicas do terapeuta que produzem melhores resultados em uma terapia FAP.

As sessões serão filmadas e gravadas por uma câmera de vídeo e a interrupção da gravação poderá ser solicitada e avaliada a qualquer momento.

\section{Desconfortos e riscos possíveis e benefícios esperados:}

Nenhum risco específico decorrente do procedimento está sendo previsto na presente pesquisa já que se trata de um processo terapêutico que visa trazer melhoras em seus relacionamentos interpessoais. Portanto, os riscos existentes são semelhantes aos de processos psicoterapêuticos de forma geral.

É previsto que você seja beneficiado pelo procedimento proposto já que o objetivo da terapia é o de desenvolver melhoras em seus relacionamentos interpessoais.

\section{Métodos alternativos existentes:}

Outras formas de psicoterapia podem levar aos mesmos benefícios (ou semelhantes) aos previstos pelo procedimento da presente pesquisa, de modo que, caso seja de sua escolha, você pode se recusar a participar do presente procedimento, procurando outras formas de psicoterapia.

Acompanhamento, assistência, garantia de esclarecimento e seus responsáveis:

Durante toda a pesquisa a terapeuta estará atenta caso seja observado qualquer prejuízo para você, a condução da terapia será imediatamente revista. A terapeuta, a 
pesquisadora e a orientadora de mestrado estarão à disposição durante toda a pesquisa para esclarecimentos adicionais.

Liberdade do cliente se recusar a participar ou retirar seu consentimento, em qualquer fase da pesquisa, sem penalização alguma e sem prejuízo ao seu cuidado:

Mesmo que você concorde em participar, poderá a qualquer momento se recusar a participar ou retirar seu consentimento, sem penalização alguma. Será importante que você comunique sua terapeuta sobre a desistência. Você poderá discutir conosco qualquer questão ou dúvida e retirar seu consentimento, caso considere necessário. Caso seja essa sua vontade, tanto a coleta de dados como a análise de desses poderão ser interrompidas e, no caso de interrupção de ambas, todo o material coletado será destruído.

Ao final da coleta de dados, você será informado do fim do procedimento da pesquisa e poderá combinar com seu terapeuta a continuidade da terapia ou o encaminhamento para um serviço de Psicologia, se assim o desejar.

\section{Garantia do sigilo que assegura a privacidade do cliente:}

As informações prestadas por você durante os atendimentos e as gravações de sessões serão utilizadas para fins didáticos e de pesquisa, incluindo publicações científicas. Essas informações serão tratadas de forma confidencial e os seus dados pessoais, bem como quaisquer detalhes que possam permitir a identificação dos envolvidos serão modificados, de modo a garantir o sigilo absoluto.

Somente a pesquisadora, a orientadora, a terapeuta e um aferidor de concordância do grupo de pesquisa terão acesso às filmagens, sendo que todos assumirão o compromisso formal de absoluto sigilo sobre qualquer informação pertencente às sessões. 
Tal Termo de Consentimento Livre e Esclarecido foi redigido de acordo com o item IV da Resolução nº66/12, das Diretrizes e Normas Regulamentadoras de Pesquisas.

Envolvendo Seres Humanos. Qualquer informação adicional acerca desta pesquisa poderá ser obtida junto aos pesquisadores por meio dos e-mails: nataliafonseca@usp.br ou sbmeyer@usp.br.

Cordialmente,

Natalia M. da Fonseca

Psicóloga e aluna de mestrado do Departamento de Psicologia Clínica

Profa. Dra. Sonia B. Meyer

Professora Livre Docente do Departamento de Psicologia Clínica

$\mathrm{Eu}$,

R.G.: participarei do projeto de pesquisa descrito acima e declaro que estou ciente e concordo com as condições apresentadas.

São Paulo, de de 20

Assinatura do cliente 
ANEXO 3 - TERMO DE CONSENTIMENTO LIVRE E ESCLARECIDO TERAPEUTA

Prezado terapeuta,

Somos estudante e professora de pós-graduação do Laboratório de Terapia Comportamental do Instituto de Psicologia da Universidade de São Paulo e estamos estudando o treino de terapeutas por meio de workshop.

Para isso, solicitamos sua colaboração voluntária para participar de um projeto de pesquisa de mestrado, aprovado pelo Comitê de Ética em Pesquisa com Seres Humanos do Instituto de Psicologia da USP (CEPH-IPUSP), sob o número do processo: 33656014.3.0000.5561. O termo de consentimento livre e esclarecido é redigido em duas vias, sendo que uma via ficará em seu poder e outra com o pesquisador.

O CEPH-IPUSP é credenciado no Conselho Nacional de Ética em Pesquisa (CONEP) e fica localizado na Av. Professor Mello Moraes, no. 1.721 - Bloco G - Sala 27 - Cidade Universitária - São Paulo/SP. O horário de atendimento ao público é de segunda a sexta-feira das 9 h30 às $12 \mathrm{~h}$ e das $14 \mathrm{~h}$ às $16 \mathrm{~h}$. O e-mail para contato é ceph.ip@usp.br e o telefone (11) 3091-4182.

Para que você possa decidir se pode colaborar conosco, procuramos esclarecer resumidamente, a seguir, o que será feito. Se depois de ler, você tiver dúvidas e quiser esclarecimentos, estaremos à sua disposição.

\section{Justificativa, objetivos e procedimentos que serão utilizados na pesquisa:}

Nossa pesquisa consiste na condução de um atendimento psicoterápico, com sessões semanais de 50 minutos, conduzidas de acordo com os preceitos da Psicoterapia Comportamental e da Psicoterapia Analítica Funcional (FAP). A FAP 
vem sendo desenvolvida e estudada ao longo dos anos e têm recebido grande reconhecimento na área nacional e internacional da Análise do Comportamento. No entanto, há aspectos da FAP ainda a serem investigados, para que se entenda melhor quais são as melhores formas de treino em FAP para psicoterapeutas.

Deste modo, você terá uma vídeo-aula antes do início das sessões e, em determinado momento, participará de um workshop experiencial sobre FAP, após o qual dará continuidade às sessões.

Ao longo da nossa pesquisa, pedimos também a sua colaboração no sentido de não procurar outras formas de aprender a FAP - seja por meio de supervisões, textos teóricos, ou outras formas.

As sessões serão filmadas e gravadas por uma câmera de vídeo e a interrupção da gravação poderá ser solicitada e avaliada a qualquer momento.

\section{Desconfortos e riscos possíveis e benefícios esperados :}

Nenhum risco específico decorrente do procedimento está sendo previsto na presente pesquisa já que se trata de um atendimento terapêutico. Portanto, os riscos existentes são semelhantes aos de processos psicoterapêuticos de forma geral. Você poderá beneficiar-se da aprendizagem por meio da vídeo-aula e do workshop que lhe serão oferecidos.

Acompanhamento, assistência, garantia de esclarecimento e seus responsáveis:

Durante toda a pesquisa, a pesquisadora e a orientadora de mestrado estarão à disposição durante toda a pesquisa para esclarecimentos adicionais. 
Liberdade do participante se recusar a participar ou retirar seu consentimento, em qualquer fase da pesquisa, sem penalização alguma e sem prejuízo ao seu cuidado:

Mesmo que você concorde em participar, poderá a qualquer momento se recusar a participar ou retirar seu consentimento, sem penalização alguma. Será importante que você comunique sua terapeuta sobre a desistência. Você poderá discutir conosco qualquer questão ou dúvida e retirar seu consentimento, caso considere necessário. Caso seja essa sua vontade, tanto a coleta de dados como a análise de desses poderão ser interrompidas e, no caso de interrupção de ambas, todo o material coletado será destruído.

Ao final da coleta de dados, você será informado do fim do procedimento da pesquisa e poderá combinar com o seu cliente a continuidade da terapia ou o encaminhamento para um serviço de Psicologia, se assim o desejar.

\section{Garantia do sigilo que assegura a privacidade:}

As informações prestadas por você durante os atendimentos e as gravações de sessões serão utilizadas para fins didáticos e de pesquisa, incluindo publicações científicas. Essas informações serão tratadas de forma confidencial e os seus dados pessoais, bem como quaisquer detalhes que possam permitir a identificação dos envolvidos serão modificados, de modo a garantir o sigilo absoluto.

Somente a pesquisadora, a orientadora e um aferidor de concordância do grupo de pesquisa terão acesso às filmagens, sendo que todos assumirão o compromisso formal de absoluto sigilo sobre qualquer informação pertencente às sessões.

Tal Termo de Consentimento Livre e Esclarecido foi redigido de acordo com o item IV da Resolução nº66/12, das Diretrizes e Normas Regulamentadoras de 
Pesquisas Envolvendo Seres Humanos. Qualquer informação adicional acerca desta pesquisa poderá ser obtida junto aos pesquisadores por meio dos e-mails: nataliafonseca@usp.brou sbmeyer@usp.br.

Cordialmente,

Natalia M. da Fonseca

Psicóloga e aluna de mestrado do Departamento de Psicologia Clínica Profa. Dra. Sonia B. Meyer

Professora Livre Docente do Departamento de Psicologia Clínica

$\mathrm{Eu}$,

R.G.: participarei do projeto de pesquisa descrito acima e declaro que estou ciente e concordo com as condições apresentadas.

São Paulo, de de 20 .

Assinatura do terapeuta 


\section{ANEXO 4 - TERMO DE RESPONSABILIDADE}

Prezados aferidor (a) de concordância e pesquisadora,

O presente trabalho intitulado "Avaliação dos efeitos do treino em psicoterapia analítica funcional por meio de workshop sobre as habilidades terapêuticas" é uma pesquisa de mestrado da psicóloga Natalia M. da Fonseca e está sob a orientação da Profa. Dra. Sonia Beatriz Meyer, da Universidade de São Paulo. É importante que algumas condições sejam respeitadas para garantir a proteção do cliente e do material utilizado:

1. Apenas eu poderei ter acesso ao conteúdo das sessões e dos registros;

2. Deverei guardá-los e manuseá-los em local seguro e protegido da observação de terceiros;

3. Manterei sigilo absoluto sobre toda e qualquer informação presente nos registros que tive acesso, como por exemplo, identidade da terapeuta e do cliente, dados pessoais de ambos, entre outras informações pessoais íntimas relevantes.

4. Comprometer-me a devolver todo o material utilizado sem efetuar cópias ou duplicações e sem qualquer tipo de violação do material original.

$\mathrm{Eu}$,

portador do RG: realizando a atividade de para a pesquisa descrita acima me comprometo a respeitar as condições definidas nesse termo. 